University of Pennsylvania Carey Law School

Penn Law: Legal Scholarship Repository

Faculty Scholarship at Penn Law

$1-2008$

\title{
The Law and Economics of Environmental Federalism: Europe and the United States Compared
}

\author{
Michael G. Faure \\ University of Maastricht - Faculty of Law \\ Jason S. Johnston \\ University of Pennsylvania Carey Law School
}

Follow this and additional works at: https://scholarship.law.upenn.edu/faculty_scholarship

Part of the Administrative Law Commons, Comparative and Foreign Law Commons, Environmental Law Commons, and the Law and Economics Commons

\section{Repository Citation}

Faure, Michael G. and Johnston, Jason S., "The Law and Economics of Environmental Federalism: Europe and the United States Compared" (2008). Faculty Scholarship at Penn Law. 202.

https://scholarship.law.upenn.edu/faculty_scholarship/202

This Article is brought to you for free and open access by Penn Law: Legal Scholarship Repository. It has been accepted for inclusion in Faculty Scholarship at Penn Law by an authorized administrator of Penn Law: Legal Scholarship Repository. For more information, please contact PennlawIR@law.upenn.edu. 
ARTICLE

THE LAW AND ECONOMICS OF ENVIRONMENTAL

FEDERALISM: EUROPE AND THE

UNITED STATES COMPARED

\section{Michael G. Faure}

Professor of Comparative and International Environmental Law,

Maastricht University

Professor of Comparative Private Law and Economics,

Eurasmus University Rotterdam

and

Jason Scott Johnston

Robert G. Fuller, Jr. Professor and

Director, Programme on Law, the Environment and the Economy University of Pennsylvania Law School

(C) January, 2008

\section{INDEX}

Abstract........................................ 207

1. Introduction ............................. 207

2. Similarities and Differences in the Key Features of

American vs. European Environmental Law and

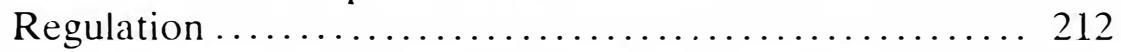

2.1. European vs. American Paths to Centralization.... 212

2.2. States vs. Nations: American Cooperative

Federalism, European Community Federalism ..... 214

2.2.1. U.S. Cooperative Federalism ............ 214

2.2.2. European National Implementation ....... 217

2.3. The Substance of Federal Standards: Uniform,

Technology-Based Command and Control versus

Market-Based Instruments.................. 221

2.4. The Role of Litigation and Environmental Interest

Groups: U.S. Standard-Setting vs. European

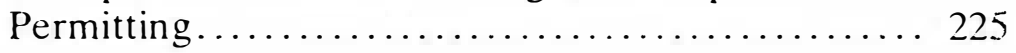


2.5. The Paradox of Centralized Environmental

Regulation for Local Pollution and the Failure of

Centralized Regulation to Effectively Address

Inter-jurisdictional Pollution ................ 229

2.6. Free Trade versus Environmental Protection ....... 233

3. The Two Economic Approaches to Environmental

Federalism ................................ 239

3.1. Normative Regulatory Federalism ............. 240

3.1.1. The Matching Principle and its

Assumptions: Decentralization versus

Centralization and Allocative Efficiency in

Public Good Provision .................. 240

3.1.2. The Possibility of Inefficient Inter-

jurisdictional Regulatory Competition:

Reevaluating the Race-to-the-Bottom

Rationale for Centralization ............. 2.t.t

3.1.3. Harmonization of marketing conditions.... 250

3.2. Public Choice and the Positive Political Economy

of Environmental Federalism ................... 251

3.2.1. Development and the Demand for

Environmental Protection: The

Convergence Thesis ...................... 254

3.2.2. Federal Level Majoritarian Politics ........ 255

3.2.3. Federal Mandates as Regional Industrial

Protectionism ......................... 256

3.2.t. Environmental Federalization, Political

Symbolism and Political Discretion ....... 257

t. Explaining and Evaluating European vs. U.S.

Environmental Law in Light of Positive and Normative

Economic Analysis of Regulatory Centralization....... 250

t.l. Is the Normative Case for Environmental

Centralization Stronger in the II.S. or Europe?

Some Suggestions and Questions ............... 259

4.2. The Paradox of Centralized Environmental

Regulation for Local Environmental Problems..... 26!

t.2.1. The Choice for I Iniform Technology-Based

Emission Standards: Regulatory

Protectionism in the EU vs. the U.S. ..... 262

4.2.2. Environmental Regulatory Centralization as an Inevitable Consequence of Divergent

Development in Majority-Rule

Federations. 
2()(9)] Environmental Federalism: Europe \& U.S. Compared 207

4.3. EU Enlargement as a Natural Experiment in the Logic and Limits of Environmental Federalism .... 267

5. Concluding remarks ........................ 271

\begin{abstract}
This article describes the evolution and key features of the centralized envirommental regulatory systems that emerged in the United States and Europe during the latter half of the twentieth century. It applies insights from the pesitive econnomic analysis of regalatory centralization in an attempt to explain a striking paralox found in both the European and American centralized envirommental regulatory regimes: that in both systems. centralized environmental regulation has been adopted not as a solution for tramsboundary pollution finter-jurisdictional externalities). hat rather for pollation that is primarily local. The paper explains that the senderncy of

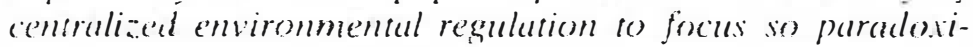
cally an localized pollution is due an inherent pressures for regional protectionism and redistrithution within a feeleral-

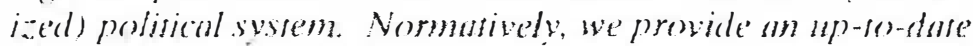
survey of the theoretical and empirical work on race-os-the' holem theery, and the'n apply normative ecomomics on deve'sp insight into the relative nermative desirability of entirommental regulatory centralization in the U.S. versus.s Europes. We helieve that the relatively lestis centralized Euro-

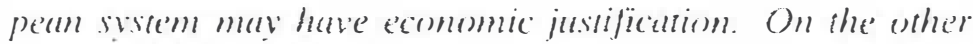
hand. the enlargement and increased e'comomic integration of Europe raise both nemmative questions resurding the desirability of centratised Eurepedon entironmenal regulation, and pesitive questions regarding she future of European entiremme'real laws.
\end{abstract}

\title{
1. INTRODUCTION*
}

In this article, we apply the tools of economic analysis to the task of explaining, and critiquing, two quite different systems of centralized environmental regulation: federal environmental law and regulation in the United States. and European Union environmental regulation. Cultural and historical factors are undoubtedly important in explaining both differences and similarities between the

\footnotetext{
: We are grateful (o) Ryan Brown (Ĺniversity of Pennsylvania) and Wanchi Tang (MaasIrich leniversity for useful research assistance and to Anna Ritat Germani. as well as to the participants in the annual conference of the European Association for law and Economics in Copenhatgen (Septemher 20017), for useful comments.
} 
European and American systems of environmental regulation. However, in our view, fundamental economic forces - such as the relative stage of development and degree of capital and labor mobility across different U.S. states and European countries - not only largely explain how and when environmental regulatory centralization took place in Europe versus the United States but also determine the economic desirability of such centralization.

This article seeks to extend two important schools of legal scholarship. The first is law and economics. Economic analysis of law constructs both positive and normative theories. Positive law and economics attempts to both explain why particular legal rules and institutions have arisen and been maintained under certain historical circumstances, and to predict the effect of such legal rules and institutions on the behavior of people subject to them. Normatively, the economic analysis of law can evaluate the efficiency and distributional consequences of alternative legal institutions. Both positive and normative economic analysis of law have focused on particular legal systems - common law or civil, for example ${ }^{1}-$ and the economic approach has not been extensively applied in the kind of comparative endeavor that we undertake below.

The second area of scholarship that we build upon is comparative law. Traditionally, comparative law is by and large atheoretic; like botany, it is content for the most part to simply observe and describe differences in national legal systems or particular areas of law. ${ }^{2}$ Such work is valuable, for it reveals the complexity of alternative legal systems, and also reveals their similarities and differences. Clearly some differences are culturally and historically determined, but when differences persist even as cultures change over time, the question is whether there may be an economic explanation for persistence and difference. That is, the persistence of difference suggests a functional explanation, that the differences reflect fundamental and systematic differences in national economic systems, which in turn determine the relative efficiency of alternative legal rules and institutions. On the other hand, one might ask, what explains similarities across national legal systems? Because there are similarities in economies that are otherwise

\footnotetext{
1 For a sustained application of economic analysis focusing on common law systems. see

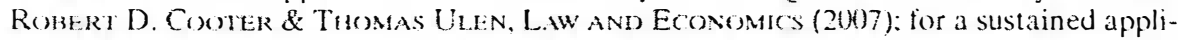
cation focusing on civil law systems, see Hans-Berni Sohater \& Clats OT\% The Ero. Nemle Andi.sis of Civil. LaW (M. Braham trans. 2005).

2 Ser, e.g. Public Environmental. Law in thr European Union and the UntTed Siates: A Comparative Analysis (René J.G.H. Seerden et al. edis.. 2002).
} 
quite different, such similarities provoke the search not only for a positive explanation of how such different diverse systems came to have similar legal rules and/or institutions, but also the natural question of how the same or similar legal rules could persist in diverse economic systems.

Economics provides a rigorous positive and normative framework to explain and evaluate legal systems across nations and federations. In this article, we describe the evolution and key features of the centralized environmental regulatory systems that emerged in both the United States and Europe during the latter half of the twentieth century. We then apply insights from the positive economic analysis of regulatory centralization to explain a striking paradox found in regimes: that both systems have adopted centralized regulations not as a solution for transboundary pollution (inter-jurisdictional externalities), but rather for pollution that is primarily local. Drawing from recent economic work on regulatory federalism, we argue that fundamental political-economic incentives account for the otherwise economically counter-intuitive focus of such federal environmental regulation on pollution problems that are largely intra-jurisdictional. Furthermore, we argue that centralized environmental regulation has had such a paradoxical focus on essentially local environmental problems, instead of evolving in response to global problems as one might assume, because there are inherent pressures for regional protectionism and redistribution within a political system.

Of course, normative public finance theory supplies economic justifications for environmental regulatory centralization other than transboundary pollution. One of these is the race-to-the-bottom story, which describes situations in which jurisdictions may fail to set locally optimal pollution standards because they are "racing" to attract mobile capital. We survey recent theoretical and empirical work on the race-to-the-bottom story, and then apply normative economics to develop insight into the relative normative desirability of environmental regulatory centralization in the United States versus Europe. While we believe that the relatively less centralized European system may have economic justification. the enlargement and increased economic integration of Europe raises some interesting questions about the value of environmental cencratization policies, including normative questions regarding the 
desirability of centralized European environmental regulation. ${ }^{3}$ and positive questions regarding the future of European environmental law.

In comparing environmental policy in the United States with environmental policy in the European Union (EU). we recognize that, in the words of one leading author, "the European Union ... does not enjoy the prerogatives of a state: it may act only where it has been expressly so authorised by the [Maastricht] Treaty [that created the EU\}," so the comparison is not entirely apples-toapples." Nevertheless, we do not view this fundamental difference - the retention of full sovereign status by the Member States of the EU - as something that precludes comparative analysis, ${ }^{5}$ but rather as a crucial factor in both explaining and evaluating the efficiency of environmental regulatory centralization. For example, because EU Member States are sovereign nations with distinct cultures and languages, there have been, until very recently, substantial barriers to mobility of capital, labor, and residency within the EU that do not exist in the U.S. Based on the race-to-the-bottom theory, the existence of such barriers significantly weakens the alse for environmental regulatory centralization. Similarly. to the extent that European nations have greatly divergent national preferences over the "environmental protection versus development" tradeoff, the case for environmental regulatory centralization is significantly weakened relative to the U.S., where there exists at the very least strong regional similarities in environmental preferenes. Henee, if the retention of sovereignty by EU Member States has entailed relatively less effective environmental regulatory centralization than in the U.S., it may be more efficient from the point of view of having environmental policies that reflect citizen preferences.

We do not write on a blank slate. Existing work has compared environmental policy in Europe and the U.S."." and compared envi-

:Our analysis here is thus consistent with previous works in law and economics argumg that far wo much authority has been allocated to the European level mere than would be necessary to cure transhoundary externalities. Se Roger Van den Bergh. The Substatarte

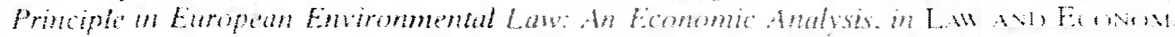

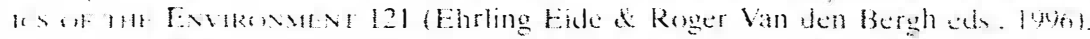

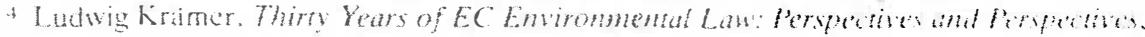

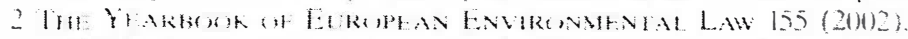

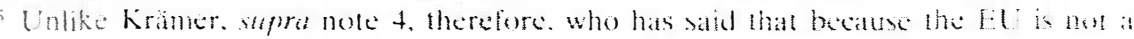
state, "Any comparison with domestic environmental law in the Member States or with that of the USA is therefore necessarily miskading."

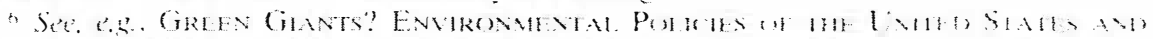

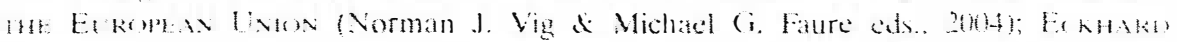

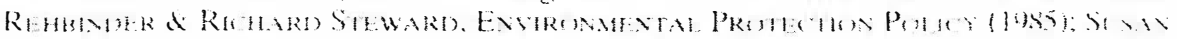


ronmental federalism in both locations generally. ${ }^{7}$ Moreover, political scientists have attempted to identify the reasons for differences in European versus American environmental federalism." These previous works differ from ours fundamentally, in that they do not systematically apply both positive and normative economic analysis. Our approach allows us to identify the likely politicaleconomic origins of fundamental differences between the European and the American systems, to normatively evaluate the relative degree of regulatory centralization in Europe versus the U.S.. and $t o$ make some tentative predictions about the impact of European political and economic integration on future changes to European environmental law.

In the second part of this article. we highlight similarities and differences between the central features of American and European environmental laws and regulations, paying attention to the division of authority between the central authority and the Member States. In the third part of this article, we provide the appropriate law andeconomics hackground for our analysis by reviewing the economic literature with respect to environmental federalism, and drawing some normative and positive conclusions from that hody of work. In the fourth part, we apply the relevant economics to explain and evaluate differences and similarities in European versus U.S. environmental law, and to make some tentative predictions about the future path of European environmental law. Finally, in our concluding remarks, we address the fundamental normative issue of how the European and American systems effec-

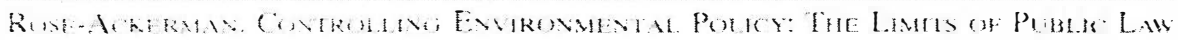

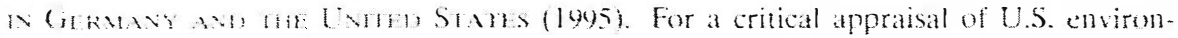
mental policy trom a European perspective. se Ludwig Kramer. The Routes of Diver.

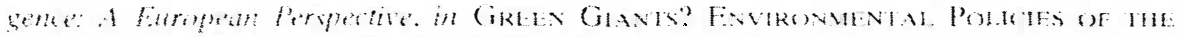

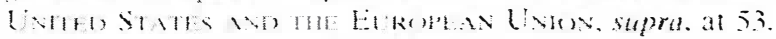

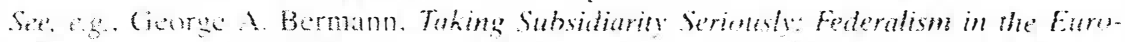

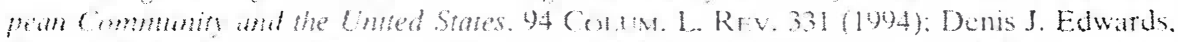

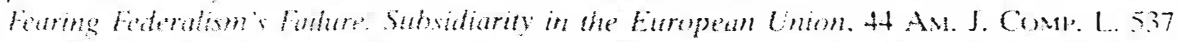

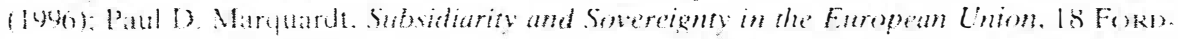

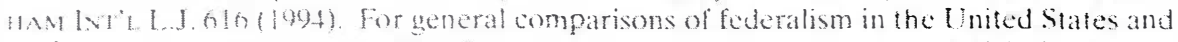

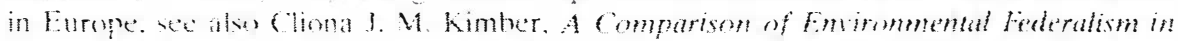

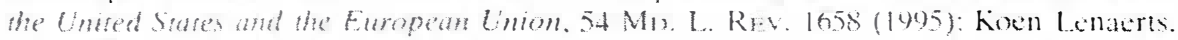

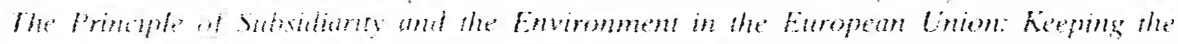

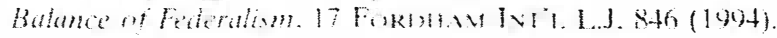

"Sex R. Dantel Kelemen. Enwhrmmental Federalism in the United States and the Eurs-

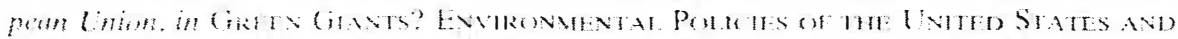

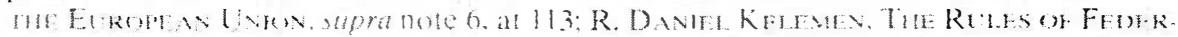

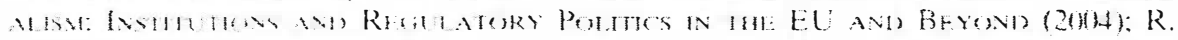

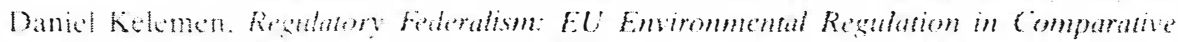

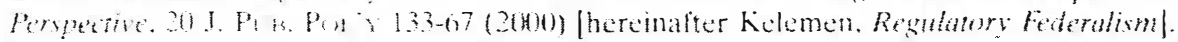


tively balance the costs and benefits of environmental protection measures.

\section{Similititifies anid Differences in the Key Features of} AMERICAN VS. EUROPEAN ENVIRONMIENTAL.

\section{LAW AND RE:GULATION.}

\subsection{European vis. American Paths to Centralization}

During the 197()'s - dubbed the "Environmental Decade" - what has been called a "new environmentalism" arose in the United States." At its core, it was a new and massive federal pollution control regulatory structure. ${ }^{10}$ To many people. American environmental regulation means federal environmental regulation. In turning to Congress rather than the states, environmentalists of the 1960 s and 1970s were simply reflecting the dominant view about federal-state relations that prevailed from 1945 until 198(): that any serious change in policy could only occur through actions by the federal government." In this preference for federal action. environmentalism was but another form of what may be called Regulatory Centralism - the view that in any hierarchical governmental system, the regulatory ideal is to transfer as much authority as possible to the highest level of government.

American environmentalists enjoyed unprecedented success in passing environmental laws. For those accustomed to legislative gridlock, it is worth recalling that within just a few years, Congress passed the National Environmental Policy Act. ${ }^{12}$ the Clean Air Amendments, ${ }^{13}$ the Federal Water Pollution Control Act Amendments. ${ }^{1.4}$ the Federal Environmental Pesticide Control Act. ${ }^{15}$ the Marine Mammal Protection Act, ${ }^{10}$ the Noise Control Act, ${ }^{17}$ the

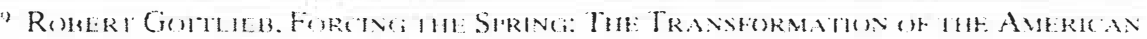

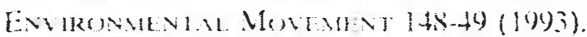

in lil. all 1.57

11 As environmental hisorian Samucl P. Hayes has satil, when it came to air and water standards. "environmentalists were convinced that state and leal governments were unreliatle. . . Hence they chose to use the federal government for leverage against the

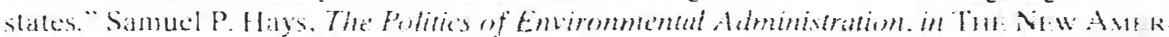

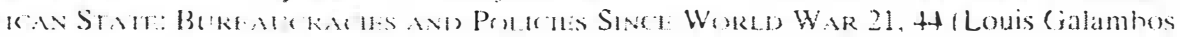
(c). 19871

12 Pub. 1.. Vu. 91-1918. 83 Slat. $552(1970)$.

13 Pub. L. No. 91-614. St Stat. 1676 (1970)).

it Puh. 1.. No. "2.-5(4) so stat. 816 (1972).

is Puh. 1. No. 42-516. So Stat. 973 (1972).

in Put. I.. No. 92-522. st Stitt. 1627 (1972).

17 Puh. 1.. No. 92-574. 56 Sta1. 1234 (1972).
} 
Coastal Zone Management Act." and the Endangered Species Act of 1973." It is fair to say that iwenty-first century Amorican emvironmental law is primarily federal. But this is not to say that all federal envirommental regulatory schemes are the same. There is significant variation among the various federal statutes. and variation too in the courts role in determining how environmental regulatory federalization has played out. Indeed, the role of the courts in American environmental federalization has been paradoxical: on the one hand. the courts have been an importam forum for citizen participation in federalized smerican environmental governance due to citizen suit provisions in the statutes: on the other hand. the courts have actively encouraged environmental federalization even at the expense of state and local regulations that may have more effectively protected the environment.

As in the United States. many European envirommental laws were enacted in the 1970s. However, at the level of the European Community (EC), there was as yet no formal legal authority, or computence, lo issue envirommental regulatory meisures. Evemually. the European Commission found the authority for environmental regulation in Articles 100 and 235 of the European Economic Community (EEC) Trealy:" Article 100 allowed for European measures te harmonize national legislation in order to remove or prevent harriers for the internal market. Article 23.5. 10 the contrary, was the (limited) legal basis for issuing legislation with a "pure" ensiromental goal. stating that if action by the Community should prove necessary to obtain one of the objectives of the community and the Treaty has not prosided the necessary powers. then The council" shall, on a proposal from the Commission and after consulting the European Parliament. take the appropriale measures. The European Court of Justice (E(J) broadly

$\therefore$ Puh. 1. Vo, y.

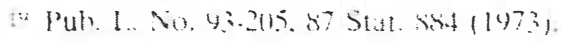

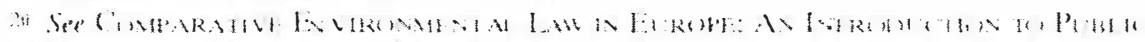

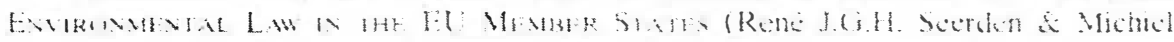

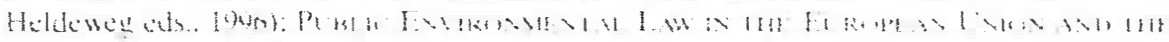

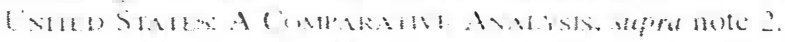

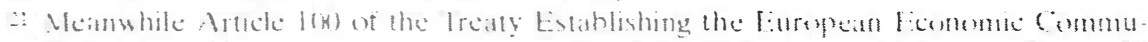
muty (E) Community (EC), and Artick 235 of the Treaty Estahlishing the EE his hecn renum.

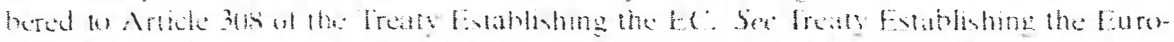

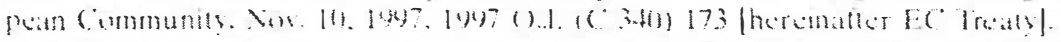

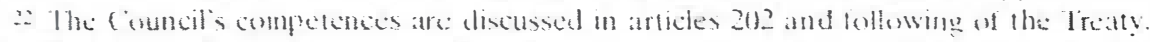

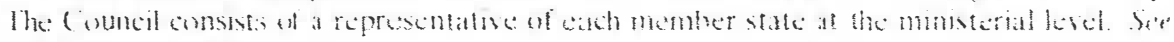

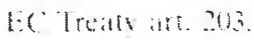


interpreted Article 235 in 1985, stating that environmental protection is one of the Community's essential objectives. However, it was only with the entry into force of the Single European Act in 1987 that the EEC Treaty was revised to include provisions ${ }^{2+}$ that specifically authorized the EC to promulgate environmental directives. $^{25}$ Since then, the European authorities have increasingly used the competences granted to them by these Articles to issue a great many directives with respect to environmental policy.

\subsection{States vs. Nations: American Cooperative Federalism. European Community Federalism}

\subsubsection{U.S. Cooperative Federalism}

The American system of federal environmental regulation does not completely displace state regulation. Rather, in the American system, regulators at the federal Environmental Protection Agency (EPA) set minimum, technology-based emission standards, ${ }^{20}$ and state regulators then generally assume the authority to implement general standards by writing plant-specific permits. and to monitor and enforce compliance with permit terms. Although there are important exceptions. ${ }^{27}$ for the most part. states are free to set state emission standards that are even tougher than federal standards. ${ }^{2 x}$ Furthermore, in translating national standards into site-specific permits, states are often legally allowed to give more weight to the cost of compliance than are federal regulators." However, state

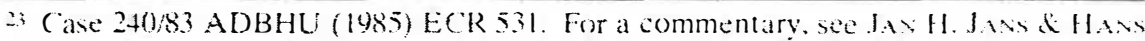

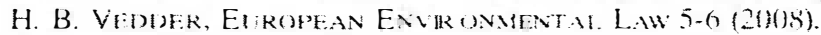

$\therefore$ EC Treaty arts. 130R-T

Is These provisions have since been renumbered. See EC Treaty arts. $17.7 \mathrm{f}$.

2o The purest example of this system of regulation is found under the Clean Water Act For a discussion, see Jason Soull Johnston. Tradable Pollution Permits and the Re'zulators

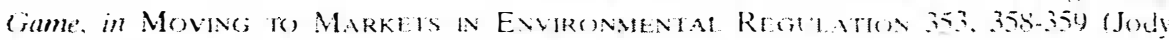
Freeman \& Charles D. Kolstad eds.. 2(1)7) $)$.

27 Perhaps most prominently, emission limits for mobile sources under the Clean Air Act are nationally unifurm. except that California can set tougher standards under certain circumstances if given a waiver by the EPA, in which case other states may follow Califor-

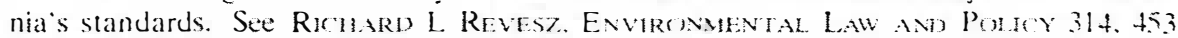
(2)(1)

2s For example, states may set water-yuality hased effluent limits that are wugher than uniform federal tehnology-hased eftluent limits. Set U.S. Steel Corp. v. Train. 556 F . 2d 8ב2 (7th Cir. 1977), and may set ambient air quality standards that are more siringent than federal National Ambient Air Quality Standards. See Union Elec. Co. v. EPA. +27 1 .S. $246(1976)$.

39 This is true, for example. under the Clean Air Act. a statute that. according to the U.S. Supreme Court, gives to the states the "initial and primary responsibility for deciding what emissions reductions will be required from which sources." Whitman v. Am. Trucking Ass'ns. 531 U.S. $457(2(x) 1)$, a responsibility that makes state environmental agencies the 
environmental regulators can be overridden by the federal EPA. both in setting permit terms for particular plants and facilities, ${ }^{36}$ and in their enforcement decisions. ${ }^{31}$

Although states are given regulatory authority by federal environmental statutes, in a few instances, through judicial interpretation, the passage of federal environmental legislation has directly diminished the role of state law in the environmental area. In the case of interstate water pollution, the Supreme Court held that the passage of the federal Clean Water Act pre-empted both the federal and state common law of interstate water pollution. ${ }^{32}$ As interpreted by the dissenting justices in the first of these cases, Milwatkee $v$. lllinois, the Court made it impossible for states with strict water quality standards to require neighboring states polluters who discharged into shared. interstate waterways to comply with those same standards; instead, the Court indicated that states only needed to require their polluters to meet federal, technologybased water pollution standards unless the polluters" home states required more.

Perhaps the most troubling example of judicial preemption of state and local environmental regulation comes in the area of noise pollution. The federal Noise Control Act (NCA) gave the federal EPA power to regulate a vast array of manufactured products, to require labeling for noisy consumer goods, as well as authorized enforcement mechanisms from citizen suits to criminal prosecution and fines. The legislation had the potent ial to change manufacturing standards for products in a broad range of industries, including aviation. railroads, trucking, motorcycles, automobiles, industrial equipment. and home and workplace appliances.

"most important forum for consideration of claims of economic and technologieal infeasibility." Union Elec. Co. v. EPA, suzra note 28.

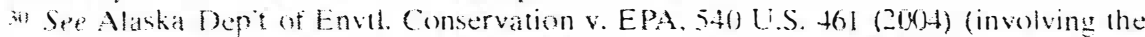
federal EPA's rejection of the state of Alaska s chosen pollution control lechnology for generator used in mining).

31 The dederal HPA has the authority to initiate enforcement action on its own when it believes that states have failed o take adequate enforement steps. See Harmon Indus. v. Browner. 19) F.id s94 (8th Cir. 19(9)).

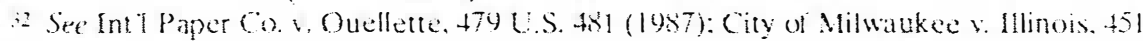
U.S. $304(1981)$.

3 See generally City of Milwaukec. stupra note 32.

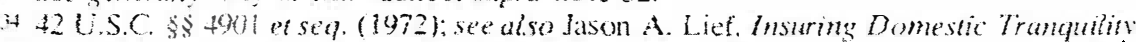

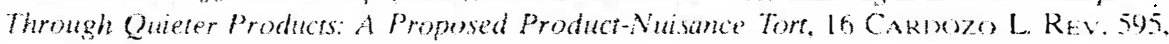
$621(1994)$.

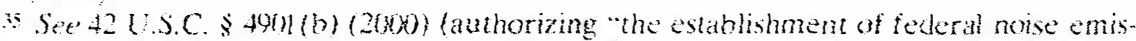
sion standards for products distributed in commerce"): $i d l$. $\$ 9() 5($ a) $)(1)(\mathrm{A})$ ( requiring regulations for products classified as a "major source of noise"). For aircraft, the NCA 
These standards were national standards which explicilly precluded state and local regulations of manufactured products that were not "identical" to federal rules. ${ }^{36}$ Local rules ostensibly were still permitted to regulate licensing, use, and movement of these products to control environmental noise. ${ }^{37}$

The EPA, however, promulgated very few noise emission standards, and the few that were approved merely codified the status quo without imposing stricter standards. ${ }^{3 .}$ Congress reacted by passing the Quiet Communities Act of 1978, a law that authorized grants for state and local noise control programs. ${ }^{39}$ This very modest start to federal noise regulation abruptly ended, however, when in 1981 the Noise Control Act was "effectively gutted" by the Office of Management and Budget's decision to terminate funding for EPA's Office of Noise Abatement and Control. ${ }^{+1}$ The decision to phase out NCA activities was based on a "determination that the benefits of noise control are highly localized and that the function of noise control can be adequately carried out at the State and local level." $"+1$

This apparent return to state and local regulation, however, was undone by implied preemption. The federal NCA may have no funding, but it remains on the books, and in City of Burbank v. Lockheed Air Terminal Inc., the Supreme Court quoted from the legislative history of that law in holding that "[s]tates and local governments are preempted from establishing or enforcing noise emission standards ... . unless such standards are identical to standards prescribed in the bill." 42 As one commentator predicted in 1981 . the end result of such judicial statutory interpretation has been that

provided for joint control over regulations between the EPA and the FAA, with the FAA retaining power to reject EPA regulations, which they did frequently. Set' John J. Jenkins Jr., The Airport Voise and Capacity Act of 1990): Has Congress Finally Solved the Aireralt Noise Problem?. 59 J. AIr L. \& Con. 1023 (199.4).

in 42 U.S.C. \$ 49() $5(e)(1)(A)(2000)$.

37 Id $\$ 4905(\mathrm{c})(2)$

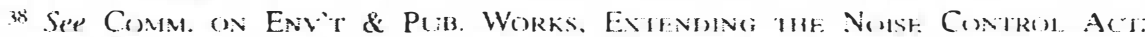

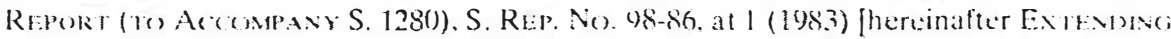

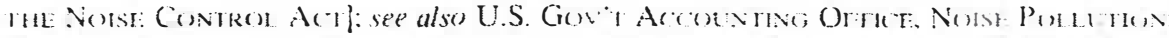

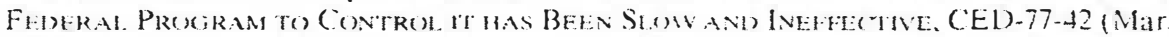

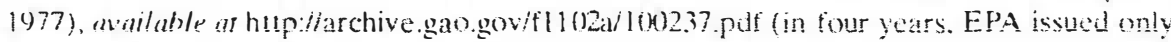
four regulations dealing with products).

3y See Aaron C. Dunlap, Come on Fiel the Noise: The Problem with Wunicipat Volse' Regulation. 15 (1. MaAm Bus. L. Rev. 47. 59 (200)6)

4i) Sere id. at (6).

4 See Exmending; The Nonse Controm. Aer. supra nole 38, at 2.

t2 City of Burhank v. Lockheed Air Terminal Inc.. +11 U.S. 624, 634 (1973). 
"the current [federal] regulations apparently will go unenforced. hut local authorities will be prevented from stepping in." +4

\subsubsection{European National Implementation}

Unlike the U.S., European "states" are sovereign nations, and in Europe today substantial environmental regulatory authority remains with the Member States. Under the so-called principle of attribution, European institutions' powers extend only as far as has heen expressly confirmed by the treaty. ${ }^{+4}$ Despite this principle, the power of the European bureaucracy (that is, the European Commission) has steadily increased and led to a steady shift of environmental regulatory competences to the European level. ${ }^{45}$ Indeed, a large portion of domestic environmental law in the Memher States today is effectively European law, and consists of European environmental directives which have heen implemented (transposed) into national law. ${ }^{\text {th }}$ For example. sixty-six percent of environmental law in the Netherlands is hased on European directives and regulations. ${ }^{-77}$ As European environmental law is effective only indirectly through Member State environmental laws which have come into heing or heen revised to meet European standards, ${ }^{\text {to }}$ the actual strength of European environmental law also crucially depends upon the enforcement of EC environmental law by that Member State. ${ }^{+0}$ Still. in the landmark Fruncovich case of November 19, 1991. the ECJ held that under certain circumstances. citizens who have suffered damage as at result of a lack of implementation by a Member State can be entitled to compensa-

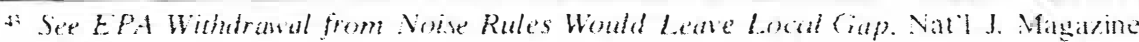

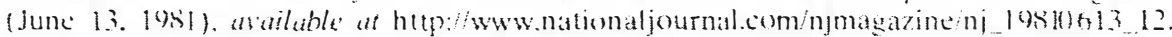
php.

th "The Communits shall at within the limits of the pewers conferred upon it by this treaty and of the ohjectives assigned to it therem". EC Ireate art.5. he' also Javis de VHADTR. supra note 2323. at 111-1.3.

ti On the increasing shift of competencies for the environmental policy io the European level. sce Jans \& Vrideke supra note 2323. at 3-9.

in In addition to dircelives. European law can alse consist of regulatiens which are directly applicable. As far as regulations are concerned. there is hence kess of an implementition prohlem. However, the primary instrument of environmental law and policy is

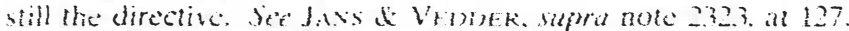

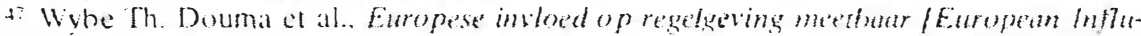

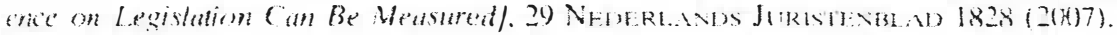

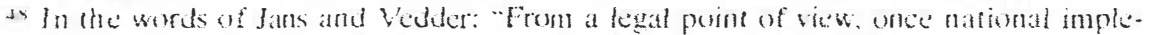
menting legislation has contered inte force. the directive is in general. no longer of interes." Jans \& Vhubt: supra nole 2323 , at 129.

1" Nany commentators describe domestic enforement as lon wealk Se Kramer. supra nute 4. at $178-5 ?$ 
tion for this damage by the Member State concerned. ${ }^{50}$ For Member States that do not implement EU law, the Francovich decision creates a form of potential liability that goes far beyond the constitutionally permissible liability of American states. ${ }^{51}$

Even more significant is the principle of direct effect, according to which any citizen can invoke European law on his behalf, even if he is challenging the policies of his own Member State. If the Member State lails to implement the EU directive within the required time, and the provisions of the directive are unconditional and sufficiently precise, an individual can directly invoke the directive's provisions, which then takes priority over national law. ${ }^{52}$ In subsequent decisions, the ECJ has used the principle of direct effect as basis for enforceable sanctions against Member States. A few years later, the ECJ imposed a financial penalty on Greece for failing to take necessary measures to comply with an earlier ECJ judgment of 1992.5. The direct effect principle also exerted influence upon a September 2(0)5 decision, whereby the ECJ held that directives can include an obligation for Member States to criminally sanction non-compliance with domestic legislation that implements a European directive. ${ }^{54}$

Although many such decisions could be viewed as evidence that the ECJ has attempted to further shift regulatory authority to the European level. we again emphasize that European law (unlike federal law in the U.S.) is not directly enforceable against citizens or enterprises. European law operates, as far as directives are concerned, only via implementation by the Member States. ${ }^{55}$ This follows from the division of competences in the EU, whercby the EU

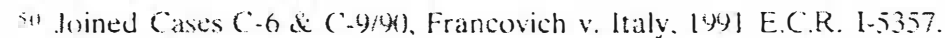

$\because$ Indeed, in Seminole Tribe of Florida v. Florida, 517 U.S. H (19)6). the L.S. Supreme Court held that Congress cannot alter the states" immunity from suit by private citizens that is granted by the Eleventh Amendment of the U.S. Constitution, unless it makes its intention lo do so "unmistakeably clear" in the language of the statute.

s2 The principle emerged in 1963 from the ECJ's holding in the well-known tan Gend de l.ow case that the European Community constitutes a new legal order which confers rights not only to the Member States, but also 10 their citizens. Case 26/62. N.V. Algement Transport- en Expeditie Onderneming van Giend \& Loos v. Neth. Inland Revenue Admin.. 196.3 E.C.R. B. Tie question whether individual rights could be found directly in Community law was, according to the court. dependent solely upon the contents and wording of the Euronean legislation concerned. with national legislation playing no role in this question. $l d$.

53 Case C-387/97, Comm'n v. Greece. 2000) E.C.R. 1-50.47 (July 4, 2014)).

it Case C $-176 / 03$. Comm v. Council (Sepr. 13, 2005).

\&5 According to article 24t9 of the EC Treaty. a directive is addressed to and binding for the Member States but it does not directly result in obligations for private individuals. Jans de Veimer. supra note 2323 at 1 s'. 
is primarily responsible for the formulation of the rules, while Member States are responsible for the rules' implementation and enforcement. ${ }^{\text {st }}$ Hence, the ECJ's case law is largely only an attempt to guarantee effective enforcement of European law against the Member States, for example by sanctioning their lack of implementation. The primary decision to shift powers to the European level with respect to a particular topic is undertaken by the European legislator, i.e., the European Parliament, the European Commission, and the Council of Ministers. ${ }^{57}$ Within this structure of competences the role of the ECJ is to guarantee that strict rules set by Brussels are also implemented by the Member States. ${ }^{\text {sx }}$

One might be tempted to analogize the judicial pre-emption of state and local environmental regulation in the U.S. to the ECJ's role in the shifting of environmental competences to European central authorities. It is true that after a European directive has dealt with a certain matter (for example, shipment of hazardous wastes), national Member States not only have an obligation to adopt their environmental laws to the contents of the directive, but - unless the dircctive specifically provides otherwise - Member States actually lose the power to take independent legal action with respect to that same area. Thus, by regulating a certain subject matter at the European level. Europe in fact pre-empts that particular issue..$^{59}$

However. similar to the American doctrine of implied pre-emption, if the ECJ finds that the area concerned has not been regulated by a European directive in an exhaustive manner, ${ }^{(x)}$ then a

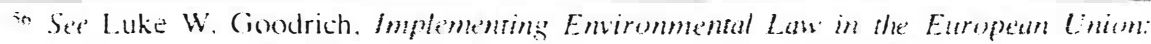

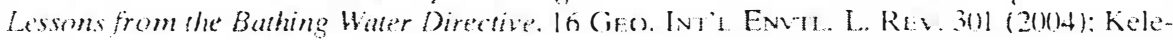
men. Regulatorv Federalism, supra note 8 , at 153.

57 According 10 article 249 of the EC Treaty. the European Partiament atting forintly with the Council and the Commission shall make regulations and issue directives. take decisions, matke recommendations or deliver opinions.

is According to article 220 of the EC Treaty. the Court of Justice and the Court of First Instance. each within its jurisdiction, shall ensure that in the interpretation and application of the Treaty the law is ohserved. Hence the Commission can bring a case hefore the court of Justice if it considers that a Member State has failed to fultill an ohligatton under the Treaty (article 226), and it has jurisdiction to give preliminary rulings concernng the validity of acts of other institutions and concerning the interpretation of the Treaty and other acts farticle $23+1$ ).

59 Sara Dillon. The Mirage of EC Envirmmental Federalism in a Reluctunt Me'mber State Juristiction. \& N.Y.U. ENvTL. L.J. I (1999).

* For example. in the well-known Council Directive 20(1)4/35/CE. 20()+ O.J. (L.14.3) .56 concerning environmental liability, various important issues such as liability in case of multi-party causation, the justificative effect of following regulation, and compulsory insur-

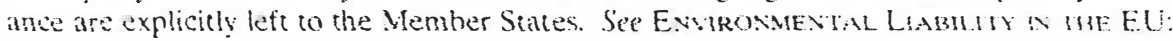


Member State may issue additional legal measures. ${ }^{61}$ On the other hand, if a European directive exhaustively regulates an area, then Member States lose their power to issue additional regulations beyond the measures of discretion allowed by the directive. Some hold that the increasing shift of powers to the European level may have an adverse effect that, for Member States with little national tradition of environmental policy, they will expect most standards to issue from Brussels, and Member States may cease to generate their own national environmental protection measures. ${ }^{62}$ That perceived danger of centralization may to some extent play a role today in the Europe of twenty-seven Member States as far as the new Member States are concerned. It certainly played less of a role in the old fifteen Member States which had already passed farreaching environmental protection measures without waiting for European action. ${ }^{13}$

Despite these similarities, there are some notable differences between pre-emption of state and local regulation in the U.S. and the shifting of environmental competences to central authorities in Europe. In Europe, there is no risk comparable to noise control regulation in the U.S., where powers would be transferred to a European agency that could pre-empt national environmental law and then leave the issue unregulated. To begin with, there is no such thing at the EU level as regulatory enforcement of environmental law. ${ }^{-1-1}$ In environmental matters, the EC does not send inspectors to check whether the law is actually applied on the ground. At the EU level, once a specific area is regulated, it is the duty of the Member State to implement the law. This is, as mentioned above, the result of the unique cooperation between Europe and the Member States, whereby the rules are set at the European level, but implementation and enforcement are entirely left to the Member States. The effectiveness of European environmental law is hence dependent upon cooperation between the EU and the

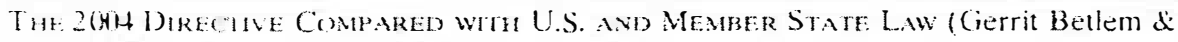
Edward Brans ads., 2(0)6).

A1 Case 278. Comm'n v. Belgium. 1979 E.C.R. 1761 ("In the ahsence of a Conmunity system guarantecing for consumers the authenticity of designations of origin. / the EC Treaty does/ not prevent a Member State from taking measures to prevent unfair pratices in that (areal. ").

6. Sete Dillon. supra note 59.

$\therefore$ On the state of environmental law in the old fifteen Member States, see (icert van

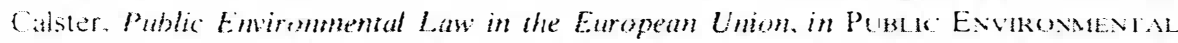

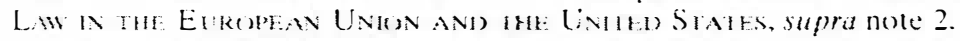

o.t There is a European Enforement Agency. hut it has no cnforcement tasks. See krimer. supra note 4 . 
Member States. ".5 The danger in Europe, and the real weakness of European environmental law, is not so much that Europe would take specific powers and preclude Member States from regulating in the same area (while Europe hypothetically does nothing), but rather that Member States may fail to implement a given directive.

There is much debate between European legal scholars about the precise qualification of the European model. ${ }^{60}$ All agree that the effectiveness of European environmental law is dependant upon cooperation between the E.U. and the Member States. Since E.U. law is not directly applicable to the Member States and the E.U. is also missing a few other legal-political features." European legal scholars usually hasten to argue that Europe is not a U.S. type federation." One US author refers to the European system as "European community federalism."

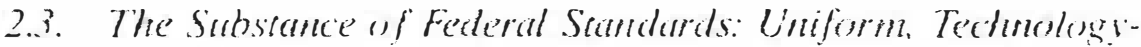 Based Command and Control versus Warket-Based lnstruments}

Major federal environmental standards in the U.S. are uniform and technology-based. For example, the Clean Water Act - which is perhaps the most successful and purest form of such a regulatory regime - requires technology-based effluent reductions that are uniform for all plants or facilities in the same industrial category and of the same age." Such standards represent the EPA s expert judgment regarding the level of effluent reduction that particular kinds of industrial plants can achieve if they install certain end-ofpipe pollution abatement technologies. ${ }^{7}$ The Clean Air Act .. which in its original version relied on state implementation (more

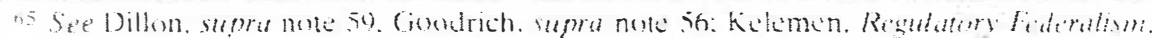
supra nutes.

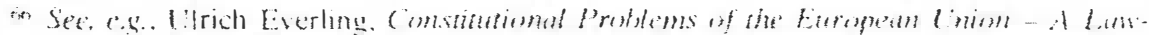

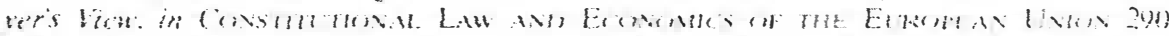

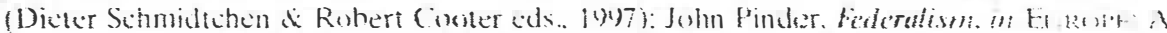

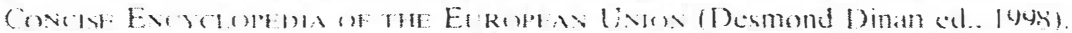

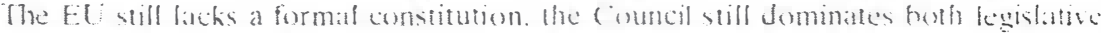

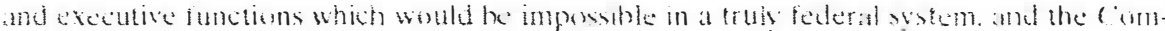

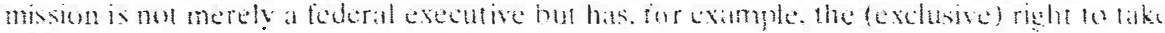
imtiatlives for legislative proposals.

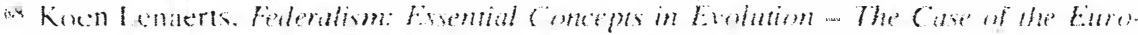

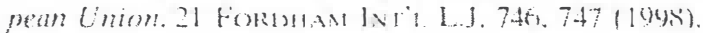

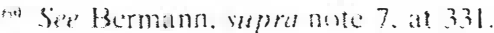

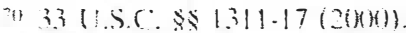

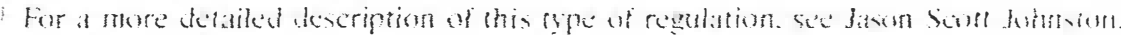

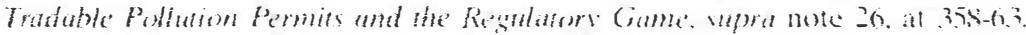


formally, State Implementation Plans) of National Ambient Air Quality Standards (NAAQS) - has likewise become much more a system of uniform, technology-based, plant-specific emission reduction standards. ${ }^{72}$

There is variation in the extent to which federal environmental statutes in the U.S. allow federal regulators to consider compliance costs in setting emission standards. At one extreme are the Clean Air Act NAAQS, where federal environmental regulators can consider only health effects - giving no weight to compliance costs. ${ }^{73}$ At the other extreme are the Safe Drinking Water Act and Toxic Substances Control Act, which respectively require the EPA to set drinking water standards so as to "maximize[] health risk reduction benefits at a cost that is justified by the benefits" $7+$ and to regulate any chemical substance that "presents or will present an unreasonable risk of injury to health or the environment. "75 These statutes not only permit but require the EPA to consider compliance costs in standard-setting. In the middle of the spectrum, as it were, are statutes such as the Clean Water Act that do not require but allow the EPA to consider compliance costs (at least for inclustry groups, if not for particular facilities) and other economic costs of regulation. ${ }^{76}$

A striking feature of federal environmental law in the United States is the complete absence of any federal environmental emission tax and the rare use of liability as a regulatory instrument. Even under the federal Comprehensive Environmental Response. Compensation and Liability Act (CERCLA) - better known as the Superfund law - which sets up an onerous joint and several liability scheme, liability is only for the costs of site cleanup and remediation. ${ }^{77}$ In the United States, while there is potential liability for natural resource damage, there is no federal environmental liability

$\because$ This is a comsequance in large part of Title $V$ which wals added in the lem amend. ments and which sels up a national permit program for an estmated 22.(0) maljor sources

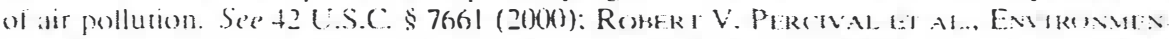

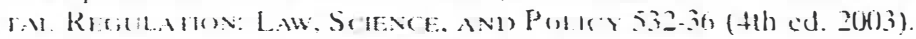

$\because$ The Supreme court reiterated this long established principle in Whman $1.4 m$.

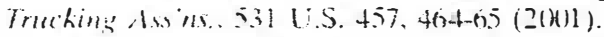

$\because$ Salle T)rinking Waler Act. 42 U.S.C. $\$ 3(x) g-1(b)(0)(A)(20()(1)$.

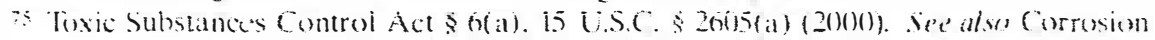
Proof Fittings v. EPA. 9.7 F.2d 121$) 1.1215$ (5th (ir. 199) (holding that this statutory language requires that the EPA adopt "least burdenseme" cost-benefit justitic regulatory alternillib).

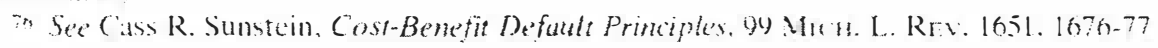
(201)

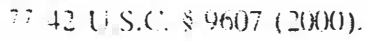


for personal injury due to environmental pollution or contamination. ${ }^{7 x}$

Traditionally in Europe, emission stanclards were inclustry-specific, but were based on administrative environmental statutes promulgated by the Member States. ${ }^{79}$ From the 197()s on. Europe has taken initiative to harmonize emission stanclards (for example. in Directive $76 / 464$ which prohibits the discharge of specific socalled grey and black list substances). ${ }^{x \prime \prime}$ In the 1980)s, quality stancards emerged which were also set at the European level. The command and control approach is most clear in Directive 96/61/EC concerning Integrated Pollution Prevention and Control (abbreviated as IPPC)." This directive holds that emission standards (referred to as emission limit values in the directive) s. $^{\text {2 }}$ have to take into account the target standard (referred to as the environmental quality standard)..$^{\times 3}$ The directive provides that these emission limit values shall be based on best available technology (BAT), but also provides that this BAT can be fixed European-wide (in other words, harmonized). ${ }^{-4}$ Thus. European environmental law is undoubtedly still reliant on technology-based, uniform standards of the traditional command and control type. This policy decision has been criticized by law and economics scholars who argue that, since local circumstances may differ. BAT should not he harmonized.".5 They also criticize the IPPC directive for considering the permit as

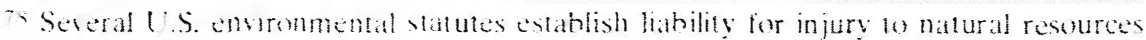

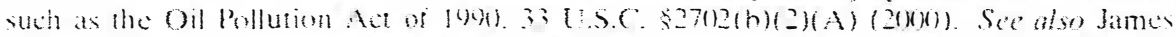

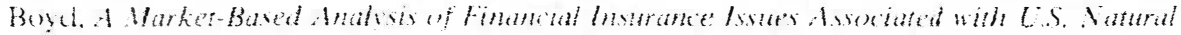

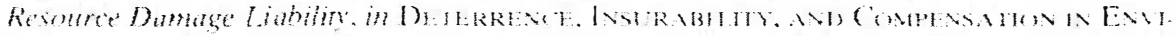

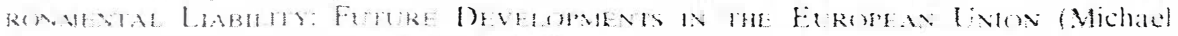

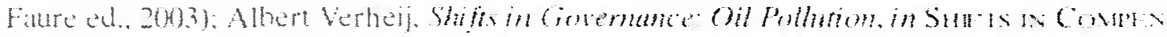

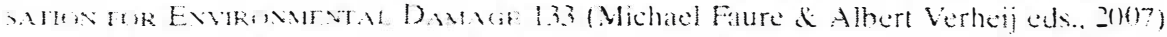

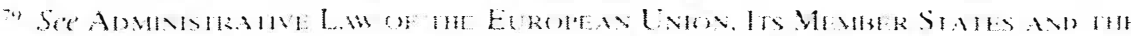

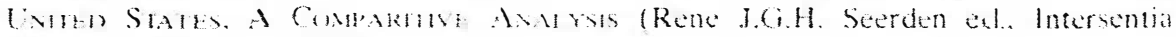

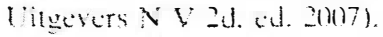

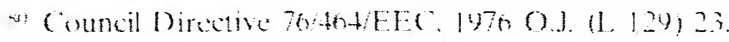

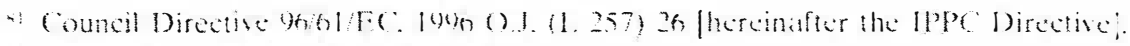

$\therefore$ Artack $2(h)$ of the IPPC Dircative.

$\therefore$ Anticle $2(7)$ at the IPPC Direnise.

ot Sce artick to (2) af the IPI' Directive which states that the Commission shall organ le an exchange of information on hest available techniques. and artick $18(1)$, which protvides for the possibility os set communty emisson limit values on the bastis of the exchange of information provided for in artick lo.

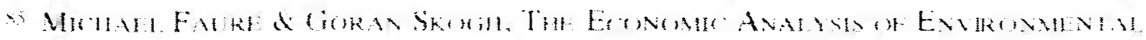

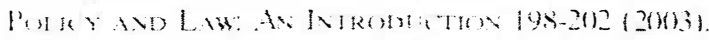


the central instrument, and not mentioning economic instruments, such as environmental taxes or emission trading. ${ }^{86}$

Notwithstanding this criticism, the notion of BAT in the IPPC Directive is interesting. It holds, on the one hand, that this is the most effective and advanced stage in the development of activities and their methods of operation, ${ }^{\times 7}$ on the other hand, the definition of "available" refers to the fact that the technique should be available "under economically and technically viable conditions, taking into consideration the costs and advantages. "מs. Hence, BAT seems to call for cost-benefit analysis.

Market-based instruments in European environmental law are still the exception. Environmental taxes (like effluent charges) are widely applied in the Member States but not at the European level."Similar to the U.S., there is one notable exception, since EU Directive 2()()3/87 of October 13, 2()()3 installed a greenhouse gas emission trading market." The European Greenhouse Gas Trading Scheme commenced on January 1, 2(1)(5), and covers the main sources that emit $\mathrm{CO}_{2}{ }^{91}$ Hence, it is fair to state that European environmental law is also largely relying on technologybased, uniform emission standards, with the $\mathrm{CO}_{2}$ emission trading scheme being the exception. Another point of similarity with the U.S. is that liability is rarely used as a regulatory instrument. While it is true that Directive 2(0)(4/35 of April 21,20()4 introduced a European-wide scheme for environmental liability, ${ }^{12}$ liability is (similar to CERCLA) only for the costs of preventive measures and for site clean-up and remediation. Just like the U.S., the European Directive provides for liability for natural resource damage.

si Mlichatel C. Faure \& J.G.J Lefevere. Integrated Pollation Prevention and Control: An

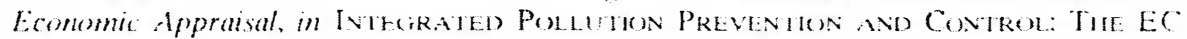

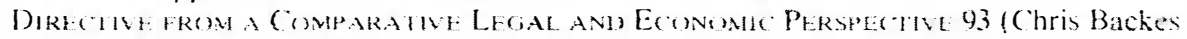
\& Cierrit Betlem eds. 10(2) ).

87 Article $2(11)$ of the IPPC directive. Note that the notion of 'activities' is as such not defined. hut refers undoubtedly to the industrial activities subject to the application of the IPPC directive.

is lal.

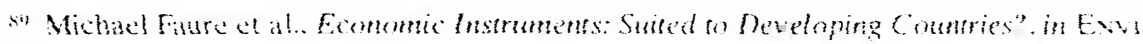

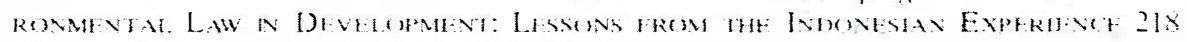
(Michael Faure de Nicole Niessen eds. 20)6)

(x) Council Directive 2003/87/EC. 20030.J. (L 275) 32.

"Warjan Pecters, Enforcement of the EU Greenhouse (ias Emissions Trading Scheme?

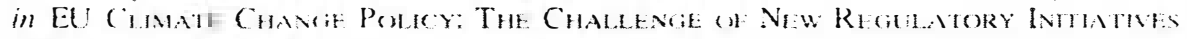
Ing (.Warjan Pecters \& Kurt Deketelatere eds. 200)t).

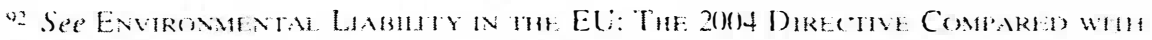

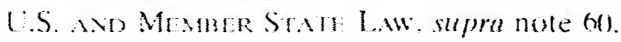


but expressly excludes environmental liability for personal injury due to environmental pollution or contamination. ${ }^{9.3}$

\subsection{The Role of Litigation and Environmental Interest Groups: U.S. Standard-Setting vs. European Permitting}

A deep structural feature of American federal environmental laws is the importance that they place on citizen litigation as an inherent part of the regulatory process. This is reflected in the environmental impact statement requirement set out in the National Environmental Policy Act (NEPA) of 1970.9.4 Rather than creating a substantive legal right to environmental protection or natural resource preservation, NEPA requires federal agencies to file an environmental impact statement (EIS) for all major federal actions significantly affecting the environment. ${ }^{95}$ Indeed, as the Supreme Court said, "NEPA does not mandate particular results, but simply prescribes the necessary process." "9o Some legal commentators have despaired that while NEPA's EIS requirement may delay some projects, it does not actually change federal agency behavior. ${ }^{37}$ It is difficult to clearly measure the impact of a law in causing agencies to not pursue projects that they would otherwise have pursued. but there is some systematic evidence suggesting that NEPA has had an important impact in slowing the pace of federal development activities. ${ }^{98}$

There are many famous cases in which, by continually pressing for detailed consideration of environmental impacts, environmentalists have caused so much delay that project developers eventually gave up. A case that is often called the first modern American environmental law case, "'s Scenic Hudson Preservation Conference v. FPC. involved a suit by a number of local non-profit organizations and municipalities seeking to halt the construction of a large pump storage plant on the shores of the Hudson River. ${ }^{(1 x)}$

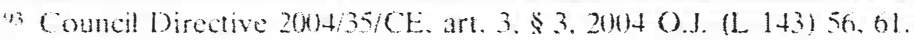

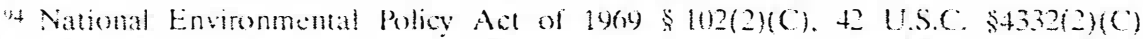
$(2(H)(1)$.

a) $l i l$.

"Roberson \&. Nethow Valley Citizens Council, tix) U.S. 332. 350 (1989).

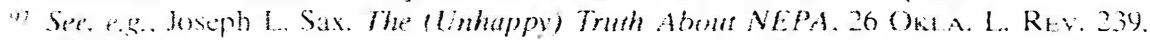
$2+5(1073)$

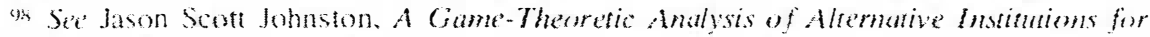
Regulatory Cost-Bentefit Analssis. 150 U. PA. L. REv. 1343. 1359 (2002) (discussing empirical evidence).

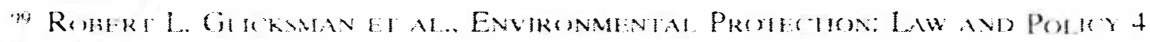
(4th ed. $2(3)$ i).

(in) 354 F.2 
Although filed in 1965, before the passage of NEPA, the plaintiffs" strategy essentially anticipated NEPA requirements: they attacked the agency`s process for failing to give them an opportunity to present evidence of environmental degradation caused by the proposed plant, and feasible alternatives to the proposal. ${ }^{101}$ In this, as in many other cases, ${ }^{112}$ it was a successful strategy: the plant was never built. Perhaps the strongest indication that NEPA's procedural requirements can actually influence and re-direct federal development activities can be found in a Bush administration proposal, which aimed to "streamline" the NEPA process by limiting the ability of citizen groups to challenge NEPA EISs' legal adequacy in court, and to allow agencies to categorically exclude entire classes of small projects from the EIS requirement. ${ }^{103}$

A distinguishing feature of American federal environmental impact review is that only federal, public projects are required to file an EIS. In European countries, the 1985 Council Environmental Impact Assessment Directive requires environmental assessments for all major public and private projects. ${ }^{\text {me }}$ There is generally considerable variation in the extent to which Member States have implemented Council Directives in their domestic laws. ${ }^{105}$ and the Environmental Impact Assessment Directive is similar in this regard, with a 1993 study finding significant crossnational variations in the number and type of environmental assessments carried out. ${ }^{16 \%}$ Insofar as such assessments must now be conducted in many European countries as part of all major private projects' permitting process, European local public participa-

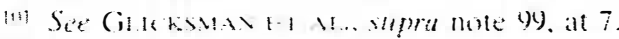

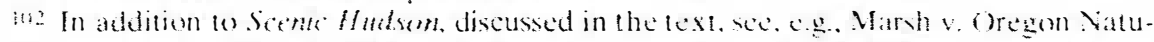

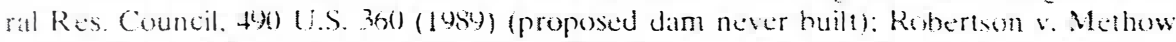
Valley Citizens (ouncil, 4 (t) U.S. 3.32 (1989) (proposed Sandy bute wi resert never developed).

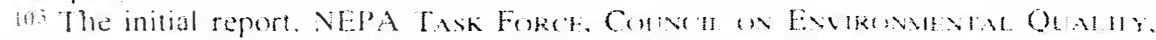

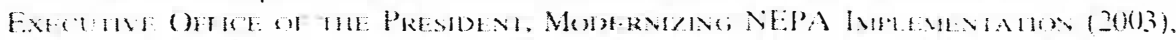

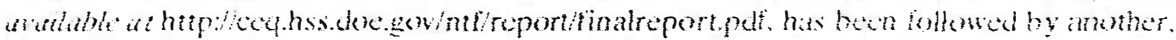

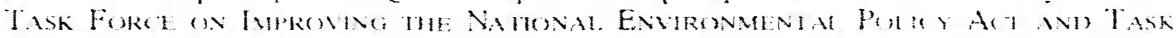

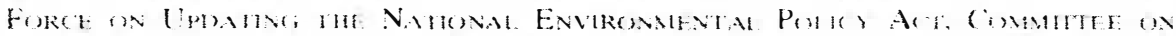

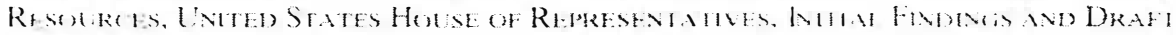

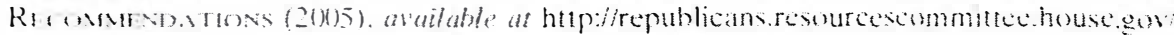
archives/iolinepalaskforce/reporthepareport_tinaldraft.pdt.

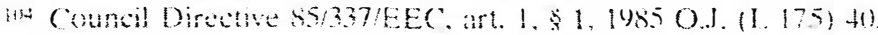

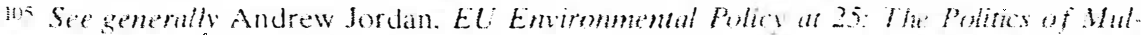

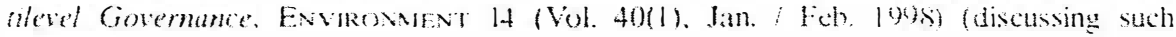
variation).

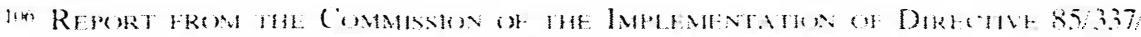

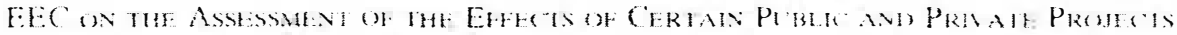

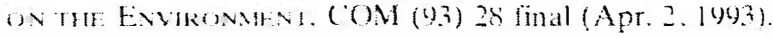


tion in determining local. facility-specific environmental standards is potentially much more significant than in the United States. On the other hand, just as under NEPA, local public participation in environmental impact assessment (EIA) in European countries does not mean that development projects are not ultimately approved.

Moreover, it seems that in Europe, project opponents have a much more limited right to seek judicial review of EIAs leading to project approval than do Americans under NEPA. ${ }^{107}$ If this is indeed the case, then the pattern of project approvals and disapprovals under European EIAs, compared against American NEPA reviews. might be used to gain insight into the influence or impact of judicial review of environmental assessment requirements upon project approval rates. The emphasis on regulatory process found in NEPA is a much more general and distinctive feature of American environmental law. To illustrate, the Administrative Procedure Act (APA) requires federal agencies to give formal public notice of, and provide an opportunity for public comment on, all proposed regulations. ${ }^{10 x}$ Moreover, if after such notice and comment. the agency promulgates a regulation, then any person "suffering legal wrong . . or adversely affected or aggrieved" by the regulation's promulgation may seek judicial review. "The scope of such judicial review is both substantive (asking. "Is the regulation consistent with the statute which it ostensibly implements?") and procedural ("Did the agency provide adequate notice of its regulation. give opportunity for public participation, and deal explicitly with the evidence presented to [it] and provide a rationalizable link between the evidence and [its] decision ".? ) $^{10}$ The Supreme Court has interpreted the scope of substantive judicial review of agency regulations in a way that requires courts to uphold any agency regulation that is a "reasonable" interpretation of the statute it implements. ${ }^{111}$ Although it may seem highly deferential. there are significant examples of agency regulations being vacated by the courts under this stanclard. ${ }^{112}$

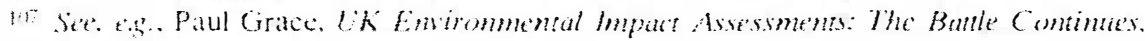

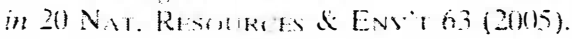

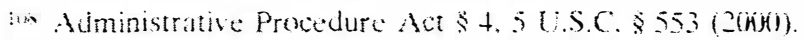

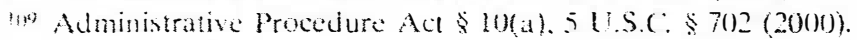

Int Mathew D. Mecubbins et al. Administrative Procedares as Instramens of Political

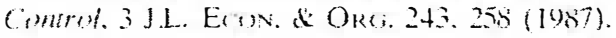

11: Chevron v. Natural Res. Def. Council. 4671 1.5. 837.844 (1984).

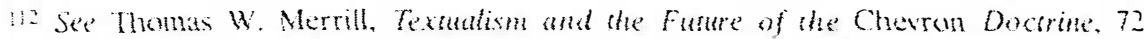
Wastl. 1: L. Q. 351 (1904). 
Indeed, some commentators on American public law believe that the combined risk that courts will overturn federal agency regulation as either procedurally or substantively flawed is so great that such agencies have become paralyzed. ${ }^{11.3}$ While a recent empirical study does not support the thesis of complete regulatory paralysis, ${ }^{14}$ whether the EPA is setting new safe drinking water standards for arsenic, or new National Ambient Air Quality Standards for fine particulates and mercury, national interest groups are actively involved at every stage of American federal regulatory standard-setting.

In contrast, the possibilities for individuals or Non-Governmental Organizations (NGOs) to challenge European Community measures (like Directives) are very limited. Under ECJ case law, direct action (based on article 230(4) EC) is only possible if the measure at hand is of "direct and individual concern." 115 In most cases, this means that NGOs or individuals have no locus standi to challenge European regulations or directives directly at the European level. ${ }^{1 / 0}$ Moreover, few European countries (if any) allow citizen groups to directly challenge proposed national environmental regulations in court. ${ }^{117}$ In such countries, individual lawsuits are brought not at the national standard-setting stage, but at the local permitting stage, where citizen groups can challenge the application of general, national environmental standards in determining the standards for a particular plant. ${ }^{1 / s}$ At least one prominent

113 Thonas o. Mc(iarity, Some Thoughts on "Deossifing" the Rulemaking Process. tl D) KE L.J. 1.365. 1+14-2011002).

114 In a recent study. Cary Coglianese finds that the expansion of judicial review did not appreciahly slow the pace of regulation by the National Highway Transportation Safety Agency (NHTSA). Cary (oglianese. The Impact of dudicial Reliew on Regularory foticy: Revamming NHTSA's Rulemaking Retreal (Jan. 2()(k) (unpublished work in progress). One reason that agencies have not heen paralyzed is hecause judges have never fully moved $t 0$ a completely deferential posture. Cy. Robert (ilicksman \& (hristopher H.

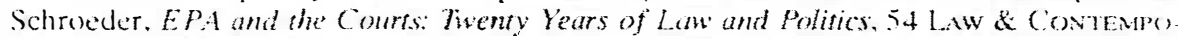
RARY PRomblents 240 (1901) (discussing possible reasons why judges have not moved to a completely deferemtial posture).

11.5 (ase 25/62 Plaumann v. Commission (1963) F:CR 95. 107. For a commentary see Jas de Velmer. supra nute 2323, at 211.

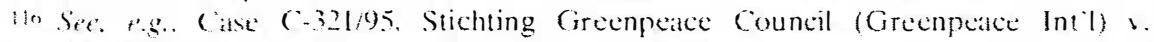

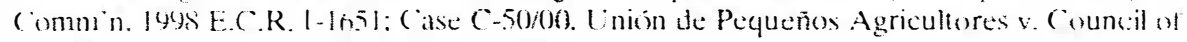

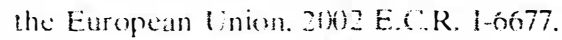

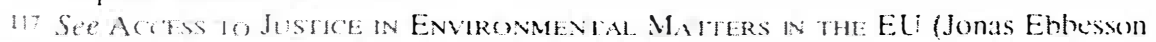

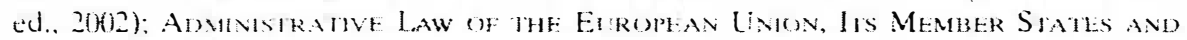

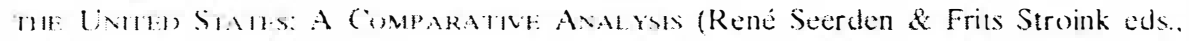
2(1) 13 ).

115 The Italian (ode of Criminal Procedure of 1989, for example, allows approved NCiOs to participate in entorcement. Douglas L. Parker. Sianding to Litigate "Abatrace 
American scholar has been harshly critical of the failure of European systems to allow public participation in and judicial review of regulatory standard-setting processes. "1" It may well be, however, that the European model allows for more active public involvement in the facility-specific permitting process than does the American system. ${ }^{120}$ If this is true, then an interesting and important topic for future research is whether this difference - more active public participation in local permitting in Europe. compared against public participation by national NGO's in standard-setting in the U.S. - has led to systematic differences in national environmental standards and local permit conditions.

\subsection{The Paradox of Centralized Envirommental Regulation for Local Pollution and the failure of Centralized Regulation to Effectively Adalress Inter- jurisdictional P'ollution}

In the U.S., federal environmental regulation is not targeted at interstate pollution. Federal environmental laws passed during the early $1970^{\circ}$ s - the heyday of the Environmentalist era - were targeted almost entirely at localized air and water pollution. ${ }^{121}$ Indeed, in some instances, those laws - such as the Clean Air Act of 197() - actually created an incentive to externalize pollution

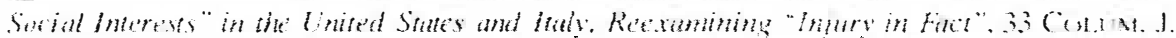
TRAvsnd i 1. 259. 29011995). In (iermany, while envirommental ansociations have relatively limitco access to the courts. persens affected directly by a proposed facility have a right to participate in the facility-specific permining process. Michat Rodi. Public Env.

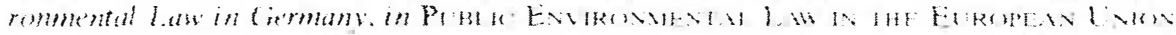

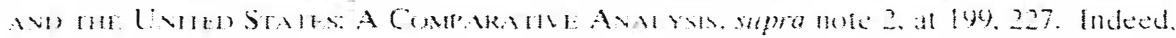
in Ciermany there are no formal procedures for the promulgation of executive regulations and adminstrative rules, hut there are quite formal procedures providing for public partisipation in major environmental permitting decisions. Hans D). Jartss \& Joseph Dikfonto.

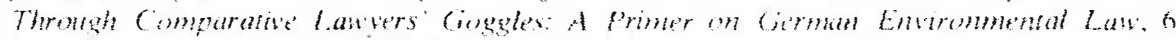

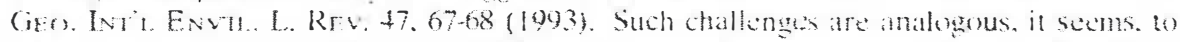

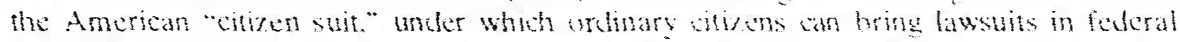
court secking to enforce permit terms against regulated ficilities. The anthegy is far from perlect, however. For European permit challenges must genterally be brought before an Admimstrative tribunal.

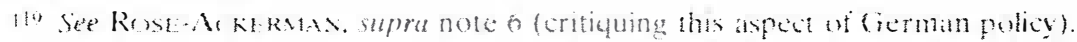

at For example in the US. a citizen cannot chathenge a site-specifie permit that incororporates the required lederal technology-hased standards and other relesant static standards. It is unclear whether this is also true in buropean coumeries.

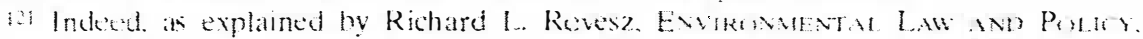
supra note 27. at +23, the main tools of laws the the original elean Air Act of 1970 atmbient quality standards and emision standiats - simply do not address interstate externalities. hecituse they do not force states or sources to tithe inte account pollution caused in atherstates. 
problems across state borders. ${ }^{122}$ Interstate transportation of sulfur dioxide emissions - the acid rain problem - was not identified as a problem until years after the Clean Air Act was passed, and was not effectively regulated under that law until it was amended in 1990) to create a national sulfur dioxide emissions trading system. ${ }^{123}$ Unlike acid rain, the paradigmatic problems dealt with by the Environmentalist era federal environmental laws - waterway pollution by municipal sewage and industrial waste, urban smog (urban air pollution due primarily to automobile emissions), safe drinking water standards, strip mining land recla mation, hazardous waste site cleanup, even the protection of wetlands from development - all involved primarily local pollution rather than interstate spillovers.

This mismatch - a national response to essentially local problems - has been criticized on a variety of grounds. ${ }^{2 .-4}$ One such crit icism is that the extension of federal regulatory authority to cover local pollution and natural resource development is unconstitutional as it goes beyond the Congressional power to regulate interstate commeree. 125 If one were unfamiliar with the way that the Supreme Court has interpreted Commerce Clause authority to regulate. then one might naturally think that the regulation of localized pollution or land development activities has nothing to do with interstate commerce, and is therefore beyond Congressional authority. Yet when confronted with such arguments, the Supreme Court has had little difficulty in finding a connection, albeit often tenuous and creatively imagined, between local pollution and interstate com-

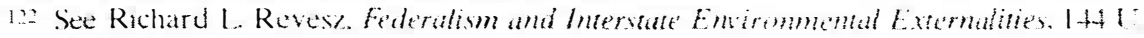
$P, 1$ L. Rtv. 23.41, 2352 (1996)

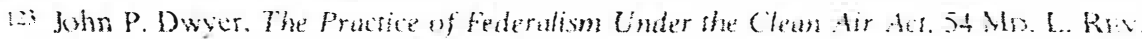
$1183,1220(1995)$. To say that the Acid Rain trading program ellectively deat with the problem of interstate sulfur dioxide pellution is an overstitement. As argued by Richard Revesz. the interstatc trading stsiem suffers from a serious defect in that its national market for permits fails to acount for the faet that pollution from souress in upwind Midwestern states causes harm to downwind Vortheastern states $(s)$ that allowing Midwestern coal burning electric utilities to simply buy permits may exacerbate the acid ratin problem in downwind Northeastern states). Richard L. Revess. Federalism and Interafate fintronmenal Externalitie's, supra note 122. at 2360-61.

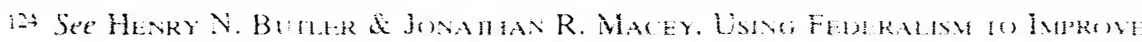

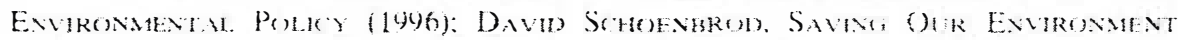

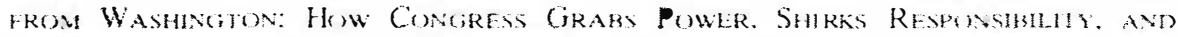
Shortehanges the Plople (2006): Jonathan H. Adler. Jurivdictional Mismatch in Enirommental Federalism. It V.Y.L. Exva. L.J. $130(2005)$.

125 See Jonathan Adler. The Ducks Stop Here? The Environmental Challenge w Federatism. in 9 Sur. Cr. Eors. Rev. $205(2(x) 1)$. 
merce. ${ }^{120}$ Following the Supreme Court's lead, federal courts have in general had an easy time justifying the constitutionality of federal environmental regulation: sometimes they found the connection between interstate markets and local pollution in the theory that local pollution is caused by interstate competition for mobile capital (the interstate race-to-the-bottom): $:^{127}$ at other times they have said that an activity such as hazardous waste disposal has an aggregate effect on interstate commerce, even though individual instances of disposal do not. ${ }^{12 x}$

The paradox of federal environmental law in the U.S. is that very little federal environmental regulation is actually directed or effective at controlling interstate pollution. For instance, the only federal regulation of interstate water pollution is that which comes ahout through the nationally uniform. technology-hased water pollution standards imposed on point sources of water pollution. The EPA has a regulation that forbids point sources from pollution discharges that violate the ambient water quality standards of another state with whom it shares a waterway, however, it is generally impossible to estahlish that a single point-source discharge in one state causes poor water quality in another state (typically downstream), ${ }^{130}$ and the EPA has vet to actually require a polluter in a "dirty" state to eut its pollution in order to meet water quality standards (including attainment or lack theresef under the Clean Water Act ) of an adjoining "clean" state. Similarly, while there was once an interstate federal common law of air pollution. ${ }^{1.3}$ for over two decades. the only effect of the Clean Air Act between 1970 and 1990) was to eliminate any control over interstate air pollution. It

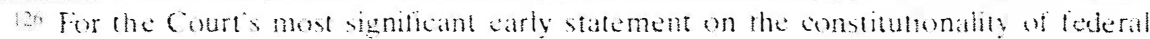
environmental laws, see Hodel v, Hidiana, +52 U.S. 314 (1981).

107 Sie? il. at $321-29$.

2. For an example of the aggregation theory appliced. see Linited States v. Olin Corp.

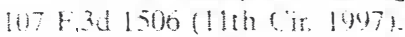

In See to (C.F.R. \& $122+4(\mathrm{~d})(2003)$.

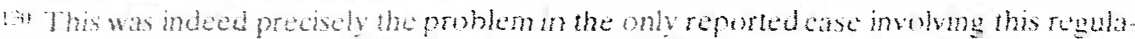

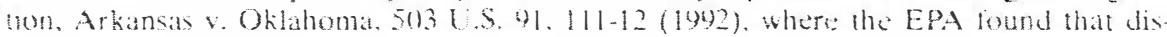
charges from an Arhansas mumeipal exalge treatment plant did not ciuse a detectable rulaton of water quatily standards in Oklahoma. the downstream state. this despite the upinion of Oblahoma offictals that the discharges from Arhansas had arned the ()klibema portion of the kiver into an "open sewer."

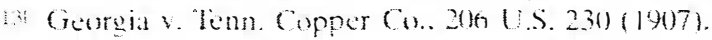

152 See Thomas W. Merrill. Golden Rules for Franshoundary Pollution. 46 Di Ke L.J. 431. 954 (1997) (discussing how no state had ever sueceded in getting reliel agatinst another state under a provision of the Clean Air Act forbidding pollution from one state that "contributes significantly" to another states failure to attain nationally uniform air yuality standardsi. 
was only with the advent of regional cap and trade regimes that the acid rain (sulfur dioxide) and ozone (nitrogen oxides and other ozone pre-cursors) interstate air pollution problems have begun to be effectively redressed in the U.S. ${ }^{1.33}$

Like federal environmental law in the U.S., a striking feature of European environmental directives is that many of them do not deal with trans-boundary or inter-jurisdictional pollution problems, but with problems that involve either both local and transboundary pollution, or even entirely local pollution ${ }^{134}$ (like Directive 76/464 concerning the discharge of dange rous substances into the aquatic environment). ${ }^{135}$ Like U.S. federal environmental law, European regulation aiming at localized pollution problems has been criticized from an economic perspective; namely, on the basis of its costs being disproportionate to the benefits received. ${ }^{1.36}$

Of course, the ECJ is not directly responsible for such "overcentralization"; it is rather the European Commission and the Member States (brought together in the Council of Ministers) that decide to regulate pollution problems at the European level, even if the economic rationale for doing so may be lacking. Still, in a number of decisions, the ECJ has either interpreted European environmental competencies broadly or has more generally facilitated the enforcement of European environmental directives against Member States. There is, for example. the aforementioned Decision of February 7, 1985 . wherein the ECJ held that environmental protection is one of the Community's essential objectives. thus justifying Community action for the environment. ${ }^{157}$ Hence, it

13 For resule on the performance of the acid rain and $V()$, erading programs, revere-

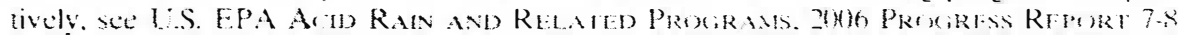

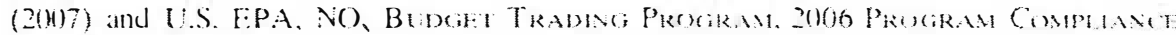

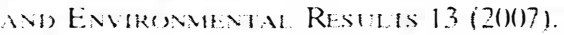

1.4 Examples of the latter are the Bathing Water Dircetive. Council Directive Th: 160 . EEC. 197h O.J. (1.031) 1. the Hahitat Dircetive. Council Directive 92/43/EEC. 19920 O.J.11. 2(h) 7 (even though that directive does not mention potlution standards, it deals with ypecies and habitat protection. which is typically a mostly local problem). and the Drinking Water Directive. Council Directive 80/778/EEC, 1980) ().J. (L 229) 11. Not surprisingly. there are many problems more particularly with the practical implementation of the bath. ing water directive. Sea Goodrich, supra note 56.

is Directive 76 tot of 4 May 1976. 1976 O. J. (1.1 2) 23

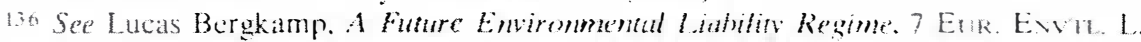

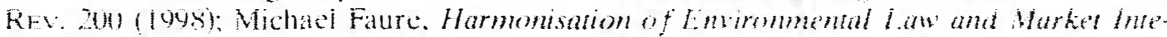

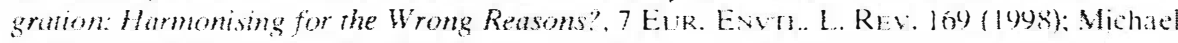
Faure d Kristel de Smedt. Should Europe Harmonise Emirommenal Liability Le gival.

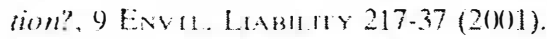

1.7 Case 240/83. Procureur de la Republique v Association de defense des bruleurs dhuiles usagees. 1985 E.C.R. 531. For a commentary see Javs $\&$ Vemer. supra note 2323 , at 5 . 
can be argued that even if the ECJ did not initiate the centralization of environmental powers, its rulings provided the stamp of approval for broad interpretations of treaty articles that facilitated such centralization. ${ }^{1 ; x}$

\subsection{Free Trade versus Environmental Protection}

In hoth Europe and the U.S., courts rather than regulators have had to determine when national environmental protection measures taken by Member States are consistent with the economic goal of free trade within an integrated economic market. In both places. state legishatures have attempted to introduce strict and far reaching environmental protection measures which may in some circumstances hinder free trade. This almost classic free trade versus environmental protection conflict has been dealt with in the U.S. under the Commerce Clause and in Europe under the Articles 28 et seg. of the EC Trealy, which aim at the promotion of economic integration in the European market.

Over the period from 1940) to 1995. American feckeral courts rarely, if ever, said that any set of activities were heyond the constitutional limits of federal regulatory authority. Throughout this period. the federal courts acted as if they were advocates for. rather than judges of the constitutionality of federal regulatory expansionism. Indeed, in the Supreme Court s jurisprudence during this time, the significance of the constitutional authorization of federal regulation of interstate commeree was not that the clause limited fecteral powers, hut that state regulations interfering with the development and operation of interstate markets were themselves unconstitutional. ${ }^{1.3}$ Under this interpretation of the Commerce Clause - known as the domant Commerce Clatuse - the Supreme Court struck down as unconstitutional state laws that limited the importation of solid municipal and industrial waste into the state and local laws that required local disposal of locally generated solid waste. ${ }^{1+1}$ The Court reasoned that such state and

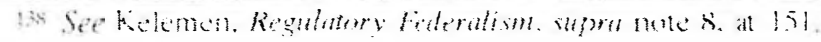

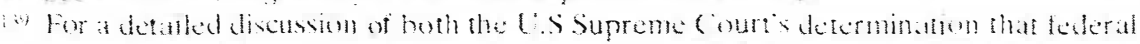

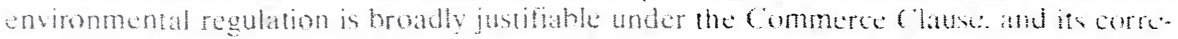

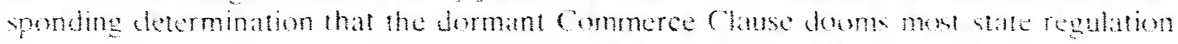
that atiempls to crate state or local self-sufficiency in managing natural resomese and

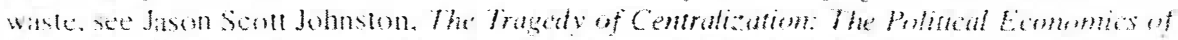

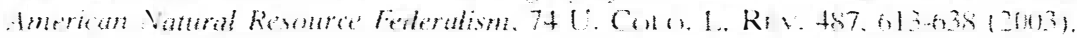

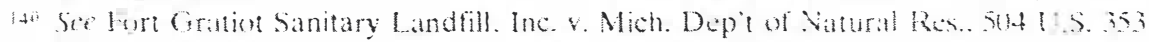

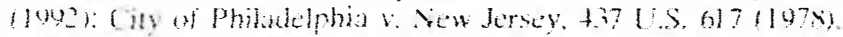

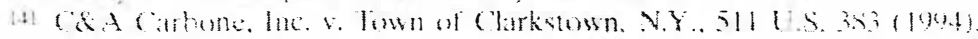


local laws had effectively created barriers to the interstate market in solid waste. As a factual matter this is correct, given that an interstate market in solid waste disposal clearly exists and did exist at the time of the Court's decisions: waste from the densely populated state of New Jersey, for example is carried by truck and rail for disposal in large, "mega-landfills" located in the less densely populated states of Pennsylvania and Ohio. Hence, if states like Pennsylvania try to ban the importation of waste and states such as New Jersey prevent solid waste exportation, they obviously interfere with the interstate market in solid waste disposal.

Such state and local laws, however, were designed to achieve local self-sufficiency in solid waste disposal. In the 1980 s, at a time of widespread concern that landfill capacity would soon be cxhausted, there was indeed a national goal of encouraging state and local governments to assume responsibility for local disposal of locally generated solid waste. By encouraging and even forcing sub-national governments in land-poor states such as New Jersey to find alternatives to land disposal of solid waste. waste import and export bans were a way to achieve that goal of waste disposal selfsufficiency. Prominent among alternatives to land disposal were waste reduction and recycling, which were generally viewed as superior to landfill disposal on environmental protection grounds. Still. there is plenty of room for landfills in states that are less densely populated. and, due in part to the advent of strict federal regulation, there are signiticant economies of scale in solid waste landfill construction and operation. Beginning in the 1990)s, the cheapest way for New Jersey towns to dispose of their municipal waste was to transport it out of state for disposal in landfills located in the relatively land-rich states of Pennsylvania and Ohio. This interstate disposal option severely weakened the incentive for New Jersey towns to reduce and recycle. Hence, hy ruling that the federal Constitution forbids state and local laws from banning solid waste imports and exports. the Supreme Court has to some degree undermined the once-national goal of creating local incentives for the reduction and recycling of municipal solid waste.

Taken together, the Supreme Court's Commerce Clause and dormant Commerce Clause cases suggest that in interpreting the Commerce Clause to further the development of the national market, the Court has often sacrificed environmental protection. ${ }^{1+2}$

1.2 In this we agree with Richard J. Lazarus, Restoring What's Environmental About Enironmental Law in the Supreme Court 4 U UCLA L. REv. 703 (2000). 
From the point of view of furthering interstate commerce. fecleral environmental regulation, while often misguided, is superior to sub-national regulation because it replaces what might otherwise be a welter of varying and sometimes conflicting state environmental laws and regulations with a system based on nationally uniform. technology-based standards. Such nationally uniform standards decrease the transaction costs of interstate industrial expansion and are. on this view of the world, desirabie. Even if it is arguably more environmentally protective, state and local environmental regulation is viewed as inherently suspect, not only because subnational variation increases regulatory compliance costs for business, but because of the strong suspicion that sub-national environmental laws and regulations are actually a disguised form of local trade protectionism.

Of course. One might argue that there was nothing that the Supreme Court could have done to avert or slow the pace of federalization anyway. In the extreme case, if Congress, in passing one federal regulatory statute after another, was simply doing what the vast majority of American voters wanted them to do. and if the courts had tried to hold such statutes unconstitutional. Congress and the people may have amended the Constitution, either to specifically authorize federal environmental legislation of a particular sort, as occurred in Germany. ${ }^{\text {th }}$ or to diminish the constitutional authority of the courts. In the alternative, perhaps such judicial intervention was unnecessary, because the A merican political system itself creates political incentives that limit federal regulatory intrusions into matters where states and localities really do want to preservet their regulatory autonomy. ${ }^{1+4.4}$

Questions such as these continue to occupy American constitutional theorists. ${ }^{1.5}$ In the meantime, the Supreme Court has taken a new look at its jurisprudence on the authority of Congress to regulate interstate commerce, and has decided that there are after all some limits on Congressional authority under the Commerce

14:3 The German federal constitution has more vpecific and stronger states rights protections than does the American constitution. and comprehensive federal air pollution legislathon in Germany did not pass until 1974. after the federal constitution had been amended to specifically authorize such federal regulation. See Raymone H. Dominiek III. THE

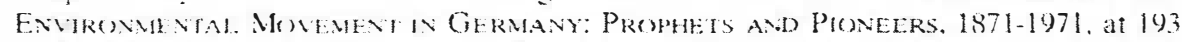
(1992): Rodi. supra note 118, at 201 (describing the constitutionally concurrent powers of the Federation and Lïnder).

$14+$ For a thorough explication of this possibility, see Larry D. Kramer. Putring the Politics Back into the Political Safeguards of Federalism. I() CoLm. I. REv. 215 (2000)).

ins See id. 
Clause." Mest importantly for purposes of this essay. the Court has decided that the federal Commere Clause does not provide carte blanche authority for fecleral environmental regulation.

Recently in Solid Waste Agency of Northern Cook County (SWANC () w Lnted States Army Corps of Engineers, ${ }^{137}$ the Court held that just because intrastate wetlands isolated from navigable waters happened to provide habitat for birds which crossed state boundaries in their annual migrations. it did not mean there was a sufticienty strong nexus to interstate commeree to provide constitutional justification for federal regulation of development in isolated wetlands (those not closely connected to navigable waters). This decision is itself ironic, in that while many local development decisions do not have inter-jurisdictional spillover effects. the aggregate effect of local decisions to develop wetlands causes a loss of habitat that seriously impairs the health of migratury bird populations, gencrating a negatibe externality that crosses not only state lines but also national borders. Indeed. federal natural resouree regulation may lairly be said to have begun with the 1906 Migratory Bird Treaty between the United States. Great Britain fof which (andata was then still a part) and Mexico. However ironic it may be. for purposes of this essiy, the most significant thing about the SWA.VCC decision is that it has heen viewed by federal regulatturs as restricting their regulatory jurisdiction. and putting the regulation of isolated wetlands hack in the hands of state and local regulatory authorities. The lesson of this case is that. if it proceeds in at suitably cautious and case-by-case manner. the Supreme (i)urt can indeed impose significan constitutional limitations on the scope of fecleral environmental regulation. limitations that do not trigger an attempt to amend the constitution to create something like a federal constiutional righ or to somehow replace or reform the Supreme Court.

Above we argued that the European legistature holds most of the decision-making authority oser the shift of powers the the Eur pean level. There is. howcver. one area in which the ECJ has clearly been the dominant actor: its case law on determining when national environmental protection measures by Member States are inconsistent with the Treatys overriding goal of European eco nomic integration. Like the U.S. Supreme Court in its Commerc Clause cases, the ECJ is the authoritative institution in decidin

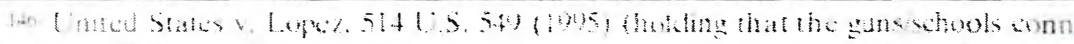

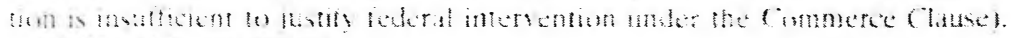

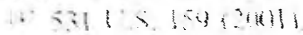


whether Member State laws and regulations violate the goal of economic integration in the European Union. The basis for this case law can be found in the FC Treaty: aceording to the provisions of Article 28 et sey. of the EC Treaty, all quantitative import restrictions and measures having equivalent effect are prohibited. ${ }^{\text {ts }}$ A Member State. therefore. cannot impose a blanket restriction on or prohibit the importation of various products on the ground that they are environmenta!ly hazardous. Such restrictions may be justified by one of the various public interest exceptions created by the Treaty itself. ${ }^{1.0}$ If such a restriction docs not fall under one of the public interest exceptions. then the ECI judges its kegality under a "rule of reatson" which permits national laws that may have an effect on the free movement of goods "in so far as these provisions may be recognized as being necessary in order to satisfy manclatury requirements." "an To survive scrutiny. under this cest. national tade-restricting measures must 1) apply in a non-discriminatory way u both national and imporked products. 2) create a mandatery reyuirement: i) hate a trate-restricting impact proportionate to the interests the measures seek to protect. and. t) not apply to an environmental issue to which a specific treaty provision applies. The gone of this ase law is to protect the functioning of the common market by preventing Hember States from using local environmental regulation to throw up barriers to frece tratce.

Thus, in applying this ruk of reason test. the $\mathrm{ECO} J$ places substantial weight on the overall E:C Treaty goal of freeing the kumpean market from trate restrictions. However. it hats alies genen weigh to the value of having. Wember States take responsibility for their usm pollution, placing it in a more thexible posture than the li.s.

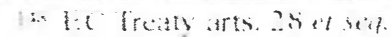

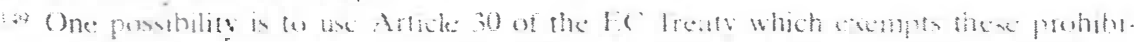

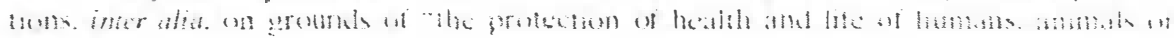
pinits".

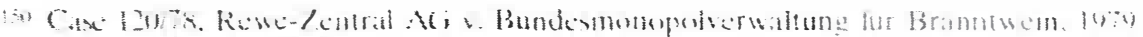

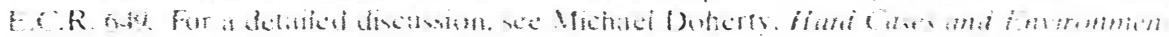

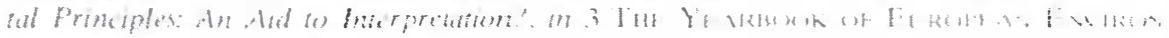

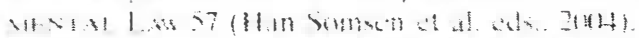

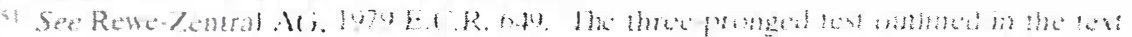

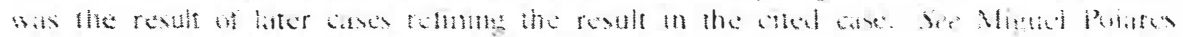

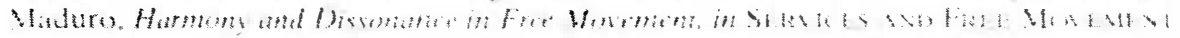

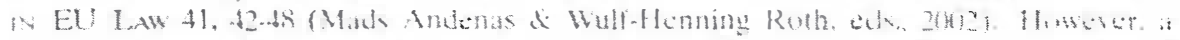

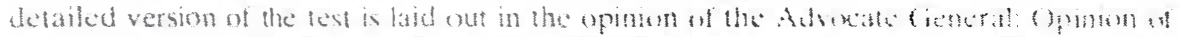

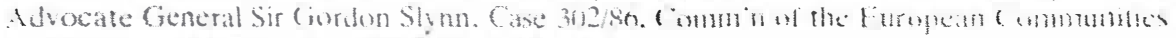

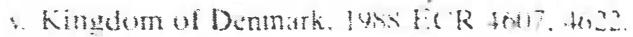

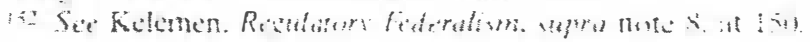


Supreme Court. For instance, in an early application of the rule of reason test, the so-called Danish Bottles case, the ECJ held that Denmark's mandatory system of returnable containers for beer and soft drinks could be justified under "environmental protection" even though that system had trade restricting effects. ${ }^{15.3}$ In 1990, the ECJ strengthened the value of environmental protection under the "rule of reason" when it decided that even though a ban on the importation of foreign waste imposed by the Dutch Walloon region was clearly discriminatory, it was nonetheless justified by the principle of "preventive action at [the] source."154 The ECJ was roundly criticized for its ruling that the principle of preventive action at the source - essentially a waste self-sufficiency principle effectively had priority over the freedom of trade and non-discrimination principles that were central to the concept of the EU. Critics not only questioned whether the Walloon measure met the proportionality requirement, but also argued that upholding import bans under the prevention-at-source principle could caușe the loss of economies of scale in waste transportation and disposal. ${ }^{155}$ Perhaps in response to such criticism, in 1996 the ECJ reaffirmed that the goal of free trade within Europe could trump the prevention-at-source principle when, in the Dusseldorp case, it invalidated export restrictions on oil filters imposed by the Dutch government. $^{156}$ The ECJ found that the clearly trade-restrictive nature of the law outweighed the Dutch government's justification that the Dutch enterprise responsible for waste management (AVR Chemie) could only operate in a profitable manner if a sufficient supply of waste could be guaranteed. ${ }^{157}$ This Dusseldorp case hence makes clear that this "prevention at the source" principle could not justify the Dutch regulation which in fact prohibited the Dutch producers to look for cheaper solutions abroad and forced them to supply the oil filters "at the source" to the Dutch waste management company.

15 Case 302/86. Comm n. Denmark, 1988 E.C.R. toll

1.4 Case (-2/99). Comm'n v. Belgium, 1992 E.C.R. I-4+31.

1 is See Peter von Wilmowsky. Waste Disposal in the Internal Market: The State of Plas:

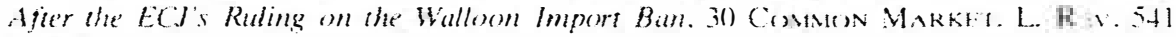
(1993).

156 Case C-203/96. Chemische Afvalstofien Dusseddorn BV y. Minister van Volkshuisvesting. Ruimtelijke Ordening en Milieubeheer. 1998 E.C.R I-4(175.

15? Morcover, the ECJ remarks that this is so "even if the national measure in yuestion could be justified by reasons relating to the protection of the environment." Se' Harrie Temmink. From Danish Bonles to Danish Bees: The Dynamics of Free Wovement of Goods

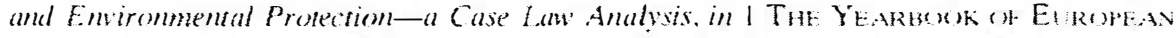
Evithonidevial. Law 7.3 (Han Somsen et al. eds. 2()()()). 
The ECJ ruling in the Dusseldorp case seems to make sense from an economic perspective: by forcing all producers of used oil filters to use the facilities of AVR Chemie, the Dutch law did indeed promote local waste self-sufficiency. On the other hand, producers were prevented from using cheaper alternatives abroad and were forced to pay monopolistic prices for waste treatment by AVR Chemie. The Dusseldorp decision of the ECJ thus can be seen as a way of exposing high cost facilities like AVR to competition and enabling producers to look for more cost effective alternatives on the competitive European market.

\section{THE Two ECONOMIC Appronches TO ENVIRONMENTAL FEDERALISM}

There are two great theoretical traditions in public economics. The first, neoclassical public finance theory, is concerned primarily with the normative question of how social-welfare-maximizing governments should set policies so as to provide and finance optimal levels of public goods. The second, public choice theory is primarily positive, with a focus on explaining how economic self-interest can explain political as well as economic hehavior. ${ }^{158}$ While there are overlaps between these two schools - with the tools of public finance increasingly being used to look at positive questions, and much of the work in public choice carrying at least implicit normative implications - the division hetween normative public finance and posicive public choice analysis is especially useful in organizing our discussion of the economic analysis of environmental regulatory centralization. On the normative side, there is a large economic literature on the question of when regulatory centralization may be socially desirable. On the positive side, the ceonomic question is when and why we observe environmental regulatory centralization. In this part of the article, we survey the normative and positive economics of regulatory centralization.

is for a comparison of these wo traditions by lwo foundational figures, see J.ams $\mathrm{M}$.

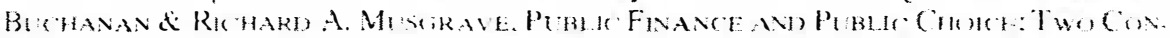

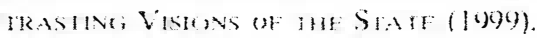




\subsection{Normative Regulatory Federalism}

\subsubsection{The Matching Principle and its Assumptions: \\ Decentralization versas Centralization and Allocative Efficiency in Public Good Provision}

Like economics in general, the normative public finance theory on regulatory federalism begins from a default position that favors regulatory decentralization and inter-jurisdictional competition. Oates" seminal "matching principle" says that if preferences over public good levels (and types) vary across local ${ }^{159}$ jurisdictions. then the overall global optimum requires varying levels (and types) of public good across jurisdictions, and this goal can be best achieved by giving control over public good provision to such local jurisdictions. ${ }^{\text {ifo }}$ On this view, decentralization improves allocative efficiency.

Recent theoretical work has shown that decentralization may have the additional benefit of improving governmental incentives in providing the public good. Essentially, this incentive effect is due to contractual incompleteness: when regulators cannot be contractually rewarded on the hasis of how well their policies satisfy citizen preferences, the best way to motivate them to adopt policies that match citizen preference is to give such citizens the right to vote out unsatisfactory politicians (and public good provision policies). ${ }^{m 1}$

The matching principle rests upon a number of assumptions, violation of any of which weakens or eliminates the case for decentralized public good provision. That is by relaxing its underlying assumptions, the matching principle generates advice as to when regulatory centralization may improve inter-jurisdictional allociative efficiency.

159 We will often use "local" to reter to any decemeralizedlevel of government, including both states and localities within countries and, in the European context, to national jurisdictions. When we wish to distinguish hetween. for cxample, state or provincial government and national government in the European context. We shall do so explicity

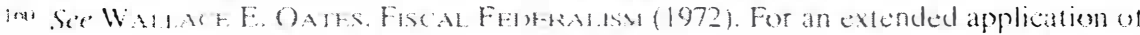
(bates matching princople bargue for the enviromental regulatory alcemeralization. sec

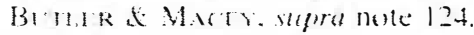

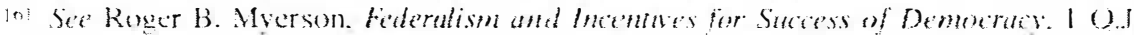

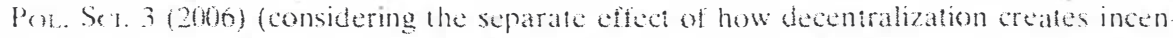
tives for gexd policies by giving local political officials a chance to establish good reputat tons that they can then use in contending for higher, national oftice): Patul Seabright.

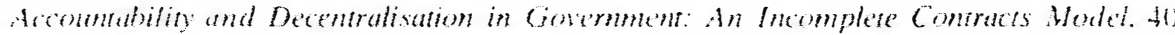

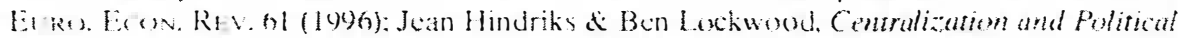

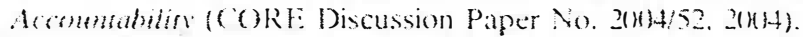




\section{(1) The Possibility of Non-Uniform Centralized Provision}

First, the matching principle assumes that if the public good is provided centrally, rather than locally, then it will be provided at a level which is uniform across jurisdictions. The allocative inefficiency of centralized provision indeed follows directly, on the matching principle, from a presumed equilibrium in which jurisdictions have varying preferences over the public good and hence varying optimal levels of provision, but the centralized authority is restricted to choosing a single level (and type) of good. ${ }^{162}$ If this is not true, and the central government can vary the level of the public good across jur isdictions and will also set the level of the public good equal to that demanded by the median voter in each jurisdiction, then centralized and decentralized provision generate identical outcomes. Now one may doubt whether the incentives facing a central legislature or regulator are really such that the regulator will set levels of public good that vary optimally across jurisdictions. but that is a positive question. one that has been addressed in the literature and which we discuss below. ${ }^{\text {th.3 }}$

\section{b) Economies of Seale. Preference Similarity and the Strong Case for Centralization}

Perhaps the most basic implicit assumption underlying the matching principle and the economic argument for decentralization is that there are no economies of scale in the provision of the public good. When such economies of scale exist, every person in a federation may be better off with cheaper, albeit uniform and nonoptimal, federal provision than with more customized but more expensive local provision. ${ }^{\text {th-t }}$ Moreover, as the degree of preference similarity across jurisdictions decreases - i.e., as people become more similar in their taste for the public good - the econo-

The Sec the discusson in Wallace E. Oates. An Fssay on Fiscal Fedoratism. 37 J. Erox. 1.11. $1121.1121-1122(1904)$.

in: Also, in the European environmental leckeralism discussion, the question has arisen whether centralization necessarily means harmonation. An obvinus alematrie is indeed 11) shift perwers flor example, hecause of ecommies of scale advantages) to the eentral level, but wh have the central authority impose differentiated standards. See e. g. Alessin. Ira Arcuri. Controlling finirommenal Rist in Furope: The Complementary Role of an EC

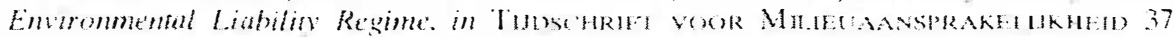
(2)(4).

low This is a consequince of Roger H. Gordon, An Optimal Taxation spproach oo fiscal federalism. 4s O.J. Eron 567 (198.3). whose model incorporates nom only economies of scalc. but inter-gurisdictonal externatities. 
mies of scale necessary to justify centralized provision become smaller and smaller.

\section{c) Inter-jurisdictional Externalities (Trans-boundary Pollution)}

Another basic assumption underlying the matching principle is that there are no inter-jurisdictional externalities in the provision of the local public good. ${ }^{16.5}$ Air and water pollution very often spillover across jurisdictional lines. however, and so the case for decentralized pollution regulation will depend in large part on whether or not one believes that local jurisdictions can themselves resolve such externalities. Now were one to assume that local jurisdictions are functionally identical to private parties, then the Coase Theorem ${ }^{1 \text { th }}$ would seem to imply that even with inter-jurisdictional externalities, the case for decentralization remains strong. After all, if the costs and benefits of pollution control are experienced locally, then it would seem that local jurisdictions have the best information about and ability to control such pollution, and so are best positioned to bargain with one another over pollution reduction. ${ }^{167}$

In addition to the obstacles to efficient private bargaining over pollution reduction, ${ }^{16 s}$ however, there are a number of obstacles to inter-jurisdictional bargaining. Fundamentally, these all have to do either with the cost and complexity of inter-jurisdictional contracting or with the lack of local political incentives to actually engage in such transactions: can one really imagine a local politician asking for higher taxes to purchase a pollution reduction commitment of dubious credibility from a neighboring jurisdiction? ${ }^{\text {fon }}$ In this light, centralized pollution regulation is necessary because it is only within the context of centralized political institutions - such

\footnotetext{
ins See Oates. An Fssay on Fiscal Federalism, supra note 162, at 1122.

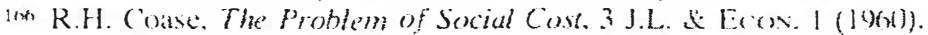

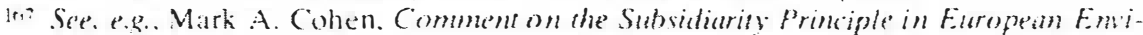

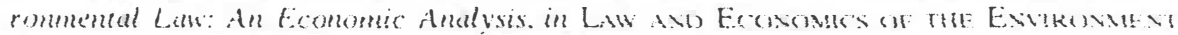
167 (Erling Eide d Roger van den Bergh eds.. 1996).

les Perhaps most importanly. incomplete inlormation about the costs and benetits of pollution reduction. See lan Ayres \& Eric Talley, Solomonic Bargaining: Dividing a Le'ga!

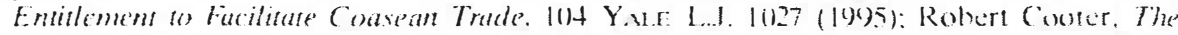

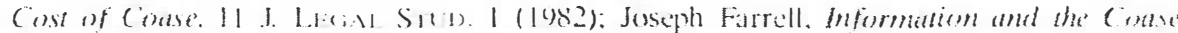

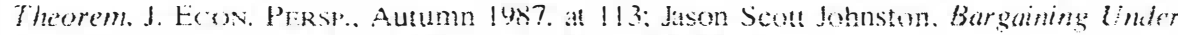

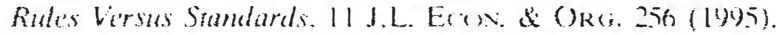

[a." On the contracting difticulties, see Tore Ellingsen. Externalitic's versus Internalitit's: A

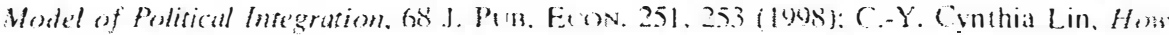

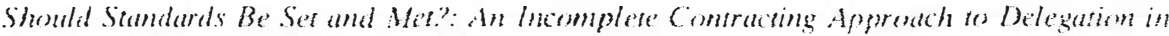

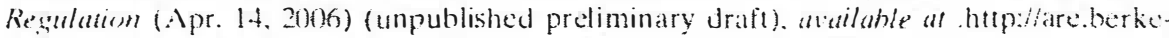
levedu/coursesiensres_seminar/20nh/delegation_paper.pdf.
} 
as central, democratically elected legislatures - that credible deals to reduce transhoundary pollution can be struck. ${ }^{7 \%}$

\section{d) Barriers to Inter-Jurisdictional Mobility}

As important as it is to understand the assumptions that are necessary for the matching principle to hold, it is just as important to understand the relationship between the matching principle and interjursidictional residential mobility. According to the famous Tiehout model, ${ }^{171}$ by "voting with their feet" and moving to the jur isdiction that offers their ideal package of public goods and taxes. residents create competition among local jurisdictions that under some circumstances can lead to a welfare maximizing outcome (jurisdictions minimize the cost of providing the full range of public good - tax packages demanded by residents). ${ }^{172}$ Such perfect mobility can enhance the efficiency gains from decentralization stressed by the matching principle. ${ }^{173}$ Conversely, even without perfect residential mobility, if jurisdictions nonetheless differ in the preference of their median voters for environmental quality versus taxes to fund other local public goods, then the efficient level of environmental quality will vary across jurisdictions, thus justifying decentralization. However, it can also be the case that if there are substantial barriers to inter-jurisdictional residential mobility, then jurisdictions will lack the preference similarity implicitly assumed by the matching principle. If, for example, there are lots of people who are high demanders of polfution reduction, but they are a substantial minority in each jurisdiction where they are found. and costs or legal rules prevent them from migrating elsewhere, then even a profit-maximizing jurisdictional entrepreneur would have no reason to offer a low pollution jur isdiction. since no one will move to it. Existing local policies set via majority rule - that is, at the level favored by the median voter - will not require hig pollution reductions, because in no jurisdiction does the median voter demand such a reduction. In this case, it is possible that a central mandate, requiring all jurisdictions to provide at least some mini-

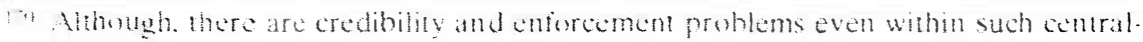

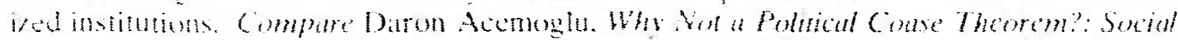

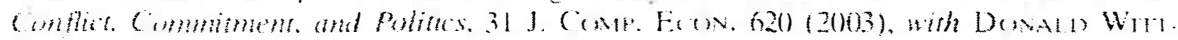

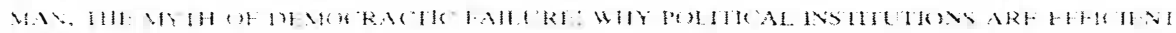
$(1,3)$

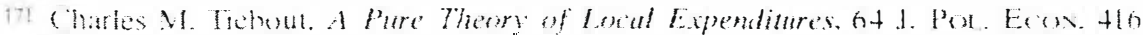
$11950)$

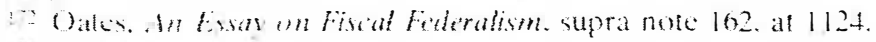

$173 \mathrm{lll}$
} 
mum level of pollution reduction, will increase overall global welfare (that is, welfare over all jurisdictions). ${ }^{174}$

\subsubsection{The Possibility of Inefficient Inter-jurisdictional Regulatory Competition: Reevaluating the Race-to-the-Bottom Rationale for Centralization}

As explained above, the matching principle presumes that by imposing pressure on local governments to provide public good levels (such as pollution reduction) that match local preferences, inter-jurisdictional competition is normatively desirable. The race to the bottom inverts this story, arguing that, far from pressuring local regulators to choose locally optimal levels of pollution reduction. inter-jurisdictional competition causes such regulators to suboptimally degrade local environments in order to attract capital and the jobs it brings. In this section, we critically evaluate the theory and evidence on the race to the bottom.

\section{(1) Theory}

The race to the bottom posits that in competing for jobs and tax revenues, jurisdictions will set inefficiently weak environmental standards. As Levinson very nicely explains, ${ }^{175}$ the race to the bottom is hasically a version of Oates' classic argument as to why redistributive taxes are impossible at the local level. ${ }^{176}$ Suppose that a local jurisdiction attempted to impose a Pigouvian tax on polluters - a tax equal to the harm they cause to the local environment - so as to reduce pollution and provide the local public good of better local environmental quality. The attempt would fail, as the taxing jurisdiction would succeed only in inducing the polluters to move to a jurisdiction that did not tax away their income.

Subsequent work in public finance theory has shown that the race (0) the bottom is in fact not a necessary result: rather, there are conditions under which local environmental regulation will provide the efficient level of pollution control. Perhaps most notably. Oate's and Schwab ${ }^{177}$ showed that if: a) all of the citizens of a jurisdiction work in the polluting industry, b) each suffers equally from

17t This has been demonsirated by Tore Ellingsen. supra note 169 . within the context if a mode! with incer-jurisdictional externalities.

175 Arik Levinson. Embirmmental Re'gututory Competions: A Staths Repert and Some

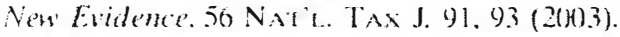

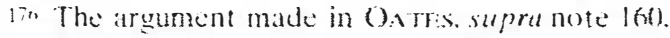

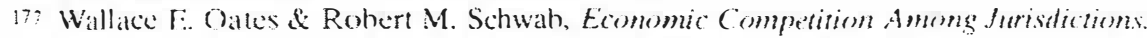

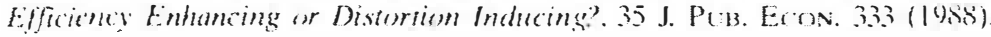


pollution, c) labor is fixed in the jurisdiction, d) capital is perfectly mobile but also competitively supplied, and finally, e) local governments choose the environmental policies that maximize the utility of the median voter, then local pollution taxes will be socially optimal. In this model, each citizen bears the full cost, yet also reaps the full benefit of reducing pollution, and hence chooses the optimal reduction in pollution (note that tax revenues are of course returned to the citizens).

Oates and Schwab's result is not especially robust with respect to variations in their underlying assumptions. For instance, if a local public good must be financed with a pollution tax on mobile capital, then the local pollution tax will be too low, so as to keep capital from fleeing the jurisdiction. Also, if some citizens work in the polluting industry and others do not, and if the median voter works in the polluting industry, then environmental regulations will be overly lax - because the more pro-environmental preferences of those who do not work in the polluting industry are disregarded. Conversely, if the median voter does not work in the polluting industry, regulations will be too strict - because the median voter does not weigh the preferences of capital-friendly laborers. Finally, local governments may pursue goals other than maximizing the aggregate utility of their citizens. ${ }^{17 x}$ These are by no means the only crucial assumptions underlying the Oates and Schwab result. As shown by Wellisch. ${ }^{170}$ the result also hinges on the use of pollution taxes: if local jurisdictions use direct command and control pollution standards rather than taxes, then external capital owners get considerable economic rents from pollution and local laborer vaters will vote to set the standards at too stringent a level.

By varying the assumptions underlying one's model of decentralized environmental regulatory competition. one can indeed generate anything from a race to the bottom, where local pollution regulations are too weak - to a race to the top, where local pollution regulations are too stringent. ${ }^{(w)}$ This theoretical ambiguity,

17s This summary of these three assumption variations is from l cevinson, whra nole 175. at $9.3-134$

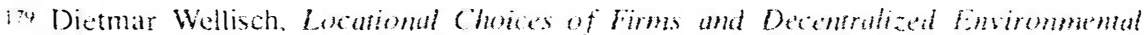
folicy with barious Instruments. 37 J. Lira. Eeon. 290 (1995).

(wi Set John I) Wilson. Capial Wobility and Environmental Standards: Is There a Theo-

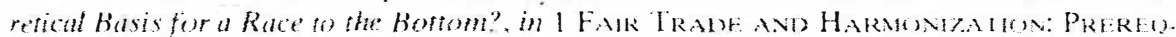

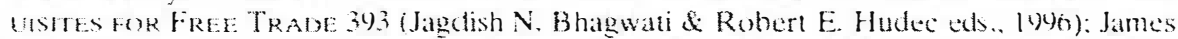
R. Markusen et al. Competition in Regienal Environmental Policies When Plant Locations

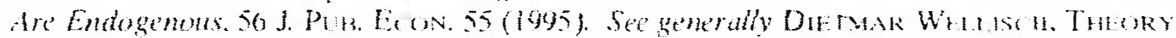

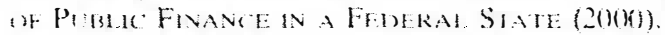


while to be expected, is somewhat unsatisfactory. The race to the bottom has been an important argument used to justify American federal (and European) environmental legislation. ${ }^{1 \times 1}$ Legal scholars continue to debate whether the race-to-the-bottom rationale justifies environmental regulatory federalization, with law and economics scholars tending to stress the benefits of competition between states or localities, ${ }^{182}$ while other legal scholars tend to believe in the validity of the race-to-the-bottom rationale for centralization. ${ }^{183}$ Given the potential significance of the race to the bottom as a rationale for environmental regulatory centralization and as a normative guide for when such centralization is economically desirable, the theoretical ambiguity suggests looking to the empirical evidence on whether or not sub-national (state and local) governments can indeed attract industry by setting lenient environmental standards.

\section{b) Empirical Evidence}

The race to the bottom is a normative story about the dangers of decentralized environmental regulation, hut it is a normative story whose key assumptions - that capital moves in response to variation in local environmental regulations, and that local regulators take such movements into account in setting regulations - virtually demand empirical investigation. For quite some time, the empirical evidence on the race to the bottom was at best weak and inconclusive. About ten years ago. Jaffe et al. summarized the empirical literature. finding that the effects of environmental regulations were "either small, statistically insignificant or not robust to tests of model specification." "lnt In their review. Jaffe et al. suggested that

1.n! The argument was expressly raised by federal legislators during dehate over the American Clean Air and Clean Water Acts fur example. Set John A. Lik de Shelhy Cicrk-

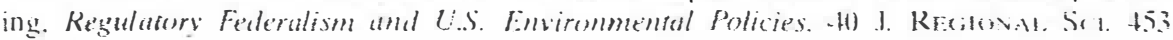
(2)( (N)).

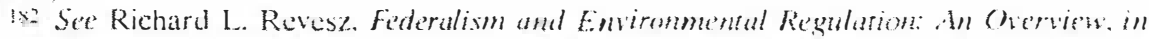

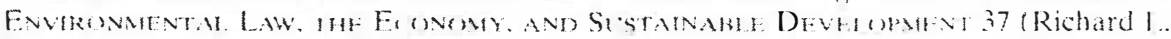
Revesz et at. eds., 2(x)(0): Revesh. Federalism and Interstate finvirmmental Externulities.

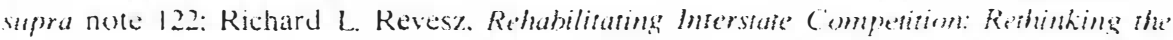

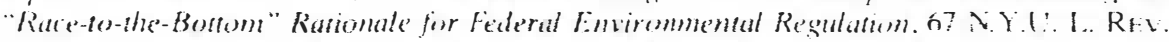
$1210(184) 2)$.

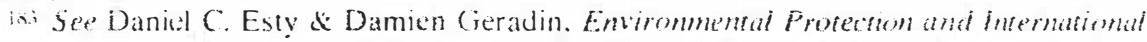
Competitivenes: A Conceptual Framentork. 32 J. WokLO TRAns: 5 (1998) phereinafter Esty ¿' Geradin. Emirommental Protection): Danicl C. Esty \& Damien Geradin. Market decess. Competiriveness, and Harmonization: Environmental Protection in Regional Trade Agresments. 21 HaRv. ENvTt. L. Rtv. 265 (1997) |hereinafter Esty di Geradin. Market Access].

15. Adam B. Jaffe et al.. Entronmental Regulation and the Comperitiventess of Li.S. Manufucturing: What Does the Evidence Tell Lis?. 33 J. Eern. LTteratukt 132 (1995). 
the stringency of environmental regulations might have some effect on new firms in their decision to locate for the first time ${ }^{\text {is }}$ but would not induce existing firms to relocate. They pointed out that other criteria such as tax levels, public service levels. and the unionization of the labor force have a much more significant impact on siting decisions than does environmental regulation.

Many economists remained somewhat skeptical of the empirical finding that environmental regulations were not a major determinant of industrial location. ${ }^{186}$ and the most recent empirical work shows that there is indeed an inverse relationship between the stringency of air quality regulations and the level of capital flows in pollution-intensive industries. The U.S. Clean Air Act distinguishes between relatively pristine "attainment" areas and more heavily polluted non-attainment areas by imposing more stringent pollution standards on the latter. ${ }^{1.87}$ Recent research has found that, even controlling for other observable factors that might influence capital movements, industrial plant growth is significantly higher in less stringently regulated attainment areas than in nonattainment areas. ${ }^{\text {si }}$ Recent work (which allows for the fact that attainment status is endogenous with respect to plant location decisions, and carefully compares places that are similar in all respects exeept attainment status) finds that being out of attainment with federal standards costs an area between ().7 and 1.3 new plants per year, a huge percentage loss given that the average county in the sample studied gets only 0.4 new plants per year. ${ }^{\text {(s) }}$ Levinson. however. argues that notwithstanding large differences in state hazardous waste disposal taxes. there has not been any pollution haven effect. He provides a variety of explanations. the most important one being that these state hazardous waste disposal

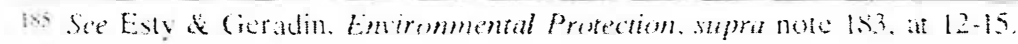

in See e.g. (harlw D). Kolstad \& Yuging Xing, Do Lax Envirmmental Regulations

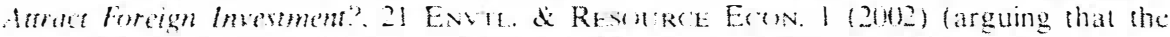
laxily of environmental regulatwons in a host country is a significant determinant of forcign dirce investment by the $4 . S$. chemical industry).

$167+2$ U.S.C. $\$ 7.022(20001)$.

twe Se' Randy A. Becker de J. Vernon Henderson, Effects of Air Qualit Regularions on

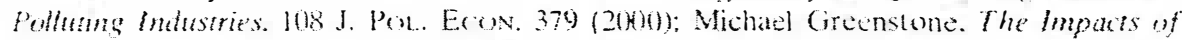

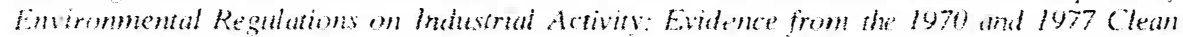
Air Aot Amendments and the (ensus of Manufacturers. 110 J. Pon. Ean. 1175 (2002).

189 John A. List et al. Effects of Environmental Regulations on Wamafacturing Plant

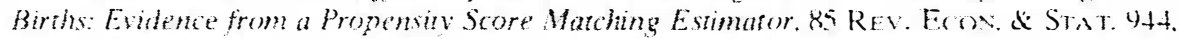
$9+8(20103)$ 
taxes do not impose large employment losses on industries that generate waste. ${ }^{190}$

Other recent empirical work has tackled the problem of controlling for the full range of variables (besides just environmental regulatory stringency) that affect firm locational choice. Working with a more detailed dataset and again employing a propensity score matching estimator, Millimet and List made the important findings that even at the very local (U.S. county) level, location-specific attributes such as unemployment levels and the overall level of manufacturing employment significantly impact the effect of environmental regulat ory stringency. ${ }^{191}$ Indeed, perhaps paradoxically, Millimet and List found that the cost of strict environmental regulations is lower both for counties with high unemployment because they have relatively abundant, cheap labor - as well as for counties with a greater concentration of employment in manufacturing - because such counties generate agglomeration economies for manufacturing firms. In summary, by using pancl datasets, and controlling for unobserved heterogeneity and regulatory endogeneity, the new empirical literature on the race to the bottom has found that environmental regulations have large, statistically significant effects on industrial location, ${ }^{192}$ effects that were previously either missed entirely or seriously underestimated. ${ }^{113}$ However, it should be stressed that most of this empirical research focuses on competition between American states; as we will discuss below. the situation may be different in Europe where there is less evidence (at least as the old Member States are concerned) of a race to the bottom.

Economists and political scientists have also empirically investigated another aspect of the race to the bottom story: whether American states do indeed compete with one another in setting environmental standards. These scholars have exploited two very important features of American environmental "cooperative feder-

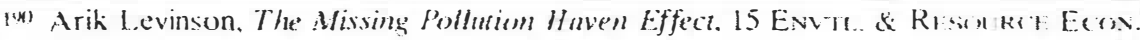
$34.3(2)(x))$.

1"I Danicl L. Millimes de John A. List, The Case of the Wissing Pollution Haven Hypoth-

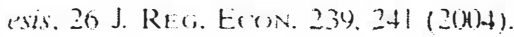

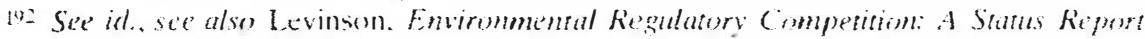
ani Some New Evidence supra note 175.

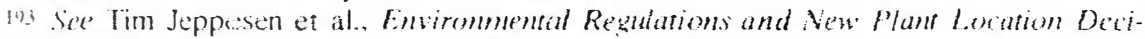

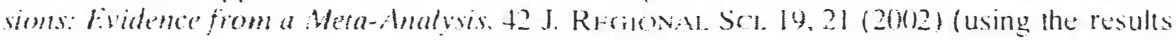
of a meta-analysis of literally hundreds of studies to show that the odd earlier results - that the locational decisions of polluting and non-polluting industries were similarly influenced by environmental regulations - may have been due to the failure of earlier studies to control for variables such as factor composition and mobility and lohbying power). 
alism": 1) federal environmental statutes generally set minimum pollution standards that states are free to toughen further if they wish: and 2) states may hecome "authorized" to have the primary responsibility for implementing (through plant-specific permits). monitoring, and enforcing federal environmental regulations. Thus, although the federal government has chief regulatory authority, the American system nonetheless gives the states sufficient discretion in both standard-setting and enforcement so that sufficient state variation might be observed in these areas to permit useful empirical tests. Recent survey work does indeed indicate substantial variation in how states exercise their discretion in standardsetting, implementation. monitoring. and enforcement. ${ }^{194}$ While some state environmental policymakers report that they feel pressure from industry to refrain from going beyond federal standards and to be forgiving (or at least flexible) in their enforcement efforts, ${ }^{125}$ other states have adopted more stringent air emission standards and conducted more monitoring than is feclerally required. ${ }^{1 \%}$ More systematic empirical work has found that variattion in state environmental enforement stringeney reflects both political and economic factors at the state level, variation across states in what may he called the political benefits and costs of envirommental regulation. ${ }^{107}$

As far as whether state environmental regulaters are acting stracegically. taking account of regulatory stringency in states with which they compele for capital and henee jobs recent empirical work has found a positive relationship between environmental reg-

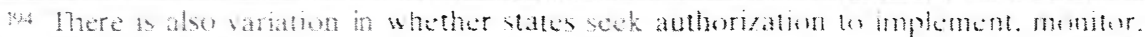

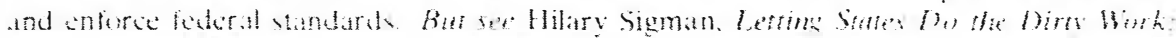

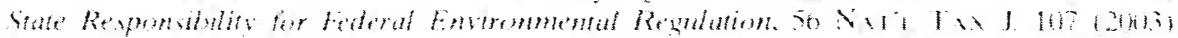

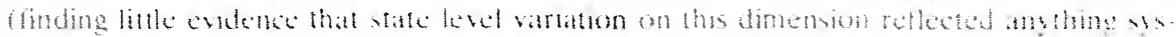

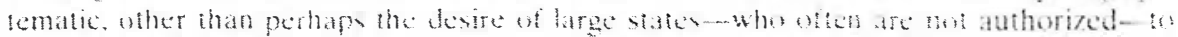

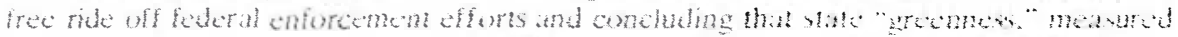

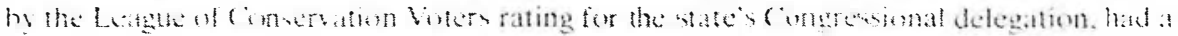

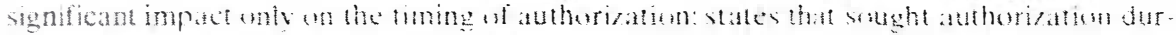

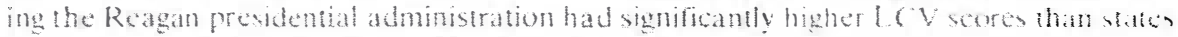

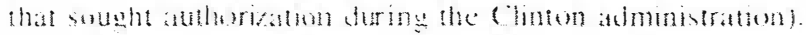

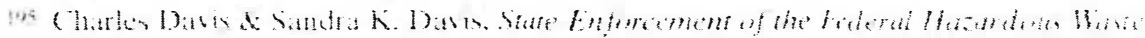

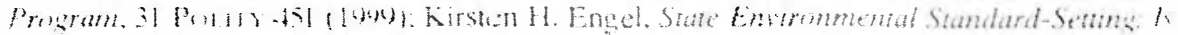

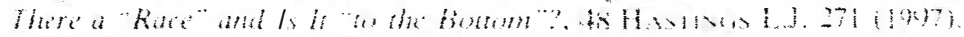

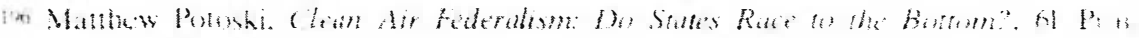

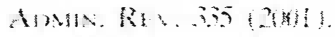

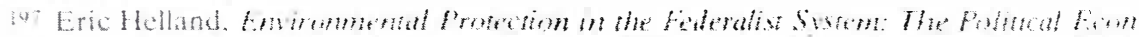

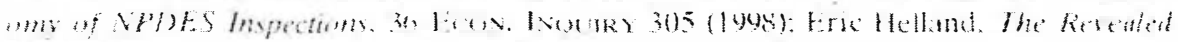

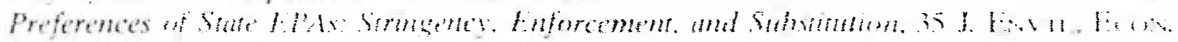

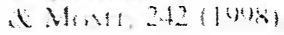


ulatory stringency (measured by normalized environmental abatement costs) in competitor states. ${ }^{\text {" }}$. Very recent work finds a similarly strong positive relationship between the environmental enforcement efforts of competitor states, with a 10 percent increase in a competitor state's enforcement efforts leading to between a 5 percent and 16 percent increase in the own state's enforcement efforts. ${ }^{(2)}$ Contrary to the race-to-the-bottom hypothesis. however, such interstate competition has been found to be symmetric: states respond to the regulatory behavior of competitor states not just by lowering their enforcement efforts to match those states with weak enforcement, but also by increasing their enforcement efforts when competitor states strengthen theirs. Thus, there is evidence that state environmental regulators are sometimes racing to the top. and sometimes racing to the bottom.

\subsubsection{Harmonization of marketing conditions}

The race-to-the-bottom argument that competition among jurisdictions for economic activity will be "destructive" corresponds, to some extent, with the European legal argument that the creation of harmonized conditions of competition is necessary to avoid trade distortions. This argument was traditionally used to harmonize legislation of the Member States in a variety of areats. Simply stated. the argument is that complying with legislation imposes costs on inclustry. If legislation differs between Member States, these costs would therefore differ as well and the conditions of competition within the eommon market would not be equal. This argument apparently assumes that total equality of conditions of competition is necessary for the functioning of the common market. "Leveling the playing field" for European industry is the central message. ${ }^{\mid(x)}$

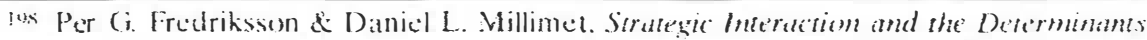

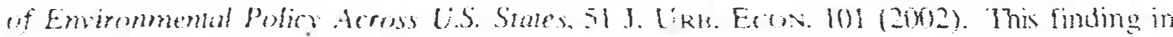
Fredrikson and Willimet was replicated hy Levinson, supra note 175.

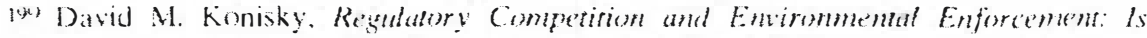

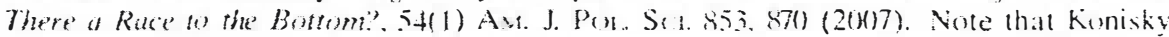
meisures statce enforecement effort with $(a)$ the annual number of sampling inspections: and (b) the unweighed sum of informal and formal enforement actions. He also uses a varicly of definitions of "competitor" states. including geographical contiguity and two regional ecommic elassifications cheloped in work by a prevous athor and abso by the Bureau of Economic Analysts thet group states in terms of their economic similarity.

In See. for example. the observations preceding Directive $76 / 46+101+$ Wal 1976 11976, (oJ (I.129) 2.3.29): "Whereas any disparity between the provisions on the discharge of certain dangerous substances into the aquatic environment already applicable or in preparation in the various Member States may create unequal conditions of competition and thus directly aftect the fuctioning of the common market." 
There are however some problems with the traditional European argument that any difference in legislation between the Memher States might endanger the conditions of competition. therefore justifying harmonization of legal rules. ${ }^{2 n}$ From an economic point of view. the mere fact that conditions of competition differ does not necessarily create a risk of a race to the bottom. There can be differences in market conditions for a variety of reasons. and if the conditions of competition were indeed totally equal, as the argument assumes, there would also be no trade.

Also, Europe has developed an claborate set of rules which promote inter clia, the free flow of products and services'2" and thus contribute to market integration without the necessity of harmonizing all rules and standards. ${ }^{203}$ In this context. the case law of the ECJ with respect to the free movement of goods versus environmental protection springs $t 0$ mind. ${ }^{2+2}$ This shows that the goal of market integration can be achieved through instruments that are less comprehensive than total harmonization ${ }^{2 n 5}$ hut can remove harriers to trade just as effectively. Hence, one should make a distinction hetween the political ideal of ereating one common market in Europe on the one hand and the (economic) race for the hottom argument on the other hand.

\section{3... Public Chosce and the Positive Political Eonnomin of Fintirommentul fecleralism}

Perhaps the paradigmatic environmental law or regulation is one that confers laree hut very diffuse henelit on a large number of victims of pollution. While imposing the much more concentrated cost of reducing that pollution on capital and labor in polluting industries. Such a law thus seems to epitomize the kind of prisoner's dilemma situation described in Mancur Olson's classic The

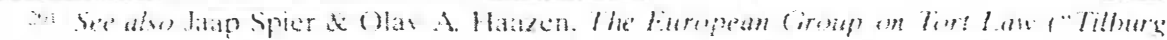

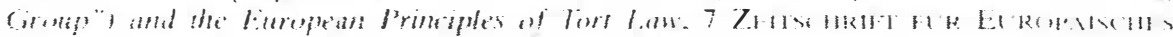
PRE $11 k 1+111+409 .+78(194)\}$.

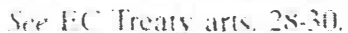

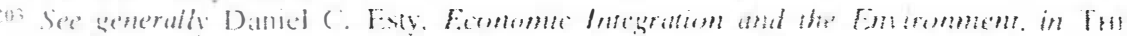

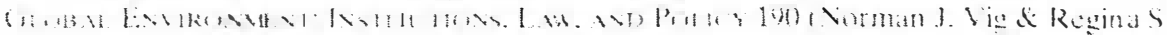

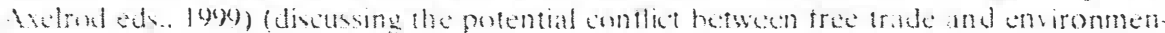
tal profecturn).

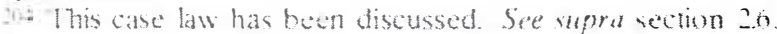

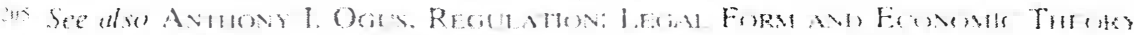

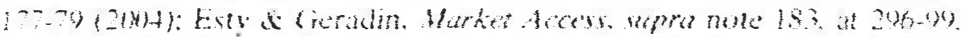

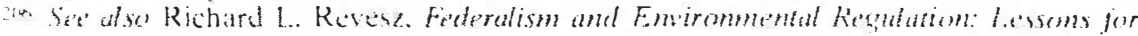

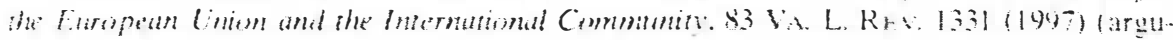
ine that the are separate pomis which should be distinguished). 
Logic of Collective Action: ${ }^{217}$ Why would anyone undertake the cost of passing environmental legislation, when the individual benefit from such legislation was so small? Moreover, how could they possibly succeed, given the very strong incentives for polluting industries to fight against environmental legislation?

The initial reaction of public choice theorists to this - what may be called the paradox of environmental protection - rellected the intellectual roots of the public choice tradition. The earliest positive economic theory of regulation, that of Stigler, ${ }^{20 \%}$ was very narrowly economic in its conception of both the benefits and costs of regulation. and essentially explained regulation as a rent-seeking game in which some firms succeeded in imposing costs on others in order to enhance their own relative competitive position. As applied to environmental legislation. Stigler's theory led economists to search for rent-seeking by firms who were using environmental legislation to impose costs on their rivals, and by environmental interest groups who were seeking to maximize their own membership and revenues. ${ }^{2(x)}$

Stigler's version of public choice theory is clearly too narrow to account for most environmental and social regulation, where the biggest winners from regulation are generally not firms, but victims of pollution and other non-industry interest groups (environmental NGOs, for example). A generalized version of this rent-seeking story - what Macey has called the political-support maximization model - presumes more broadly that politicians and regulators choose legislation and regulation so as to maximize their net politi(al support. ${ }^{21 !}$ This theory not only helps to explain regulatory behavior, hut also to explain the enactment of environmental legislation." Also, the "shadow interest group" theory presented by Keenan and Rubin explains why politicians may enact environmental regulation: demand for regulation is sometimes represented by a rather vague demand from the public, rather than by a dis-

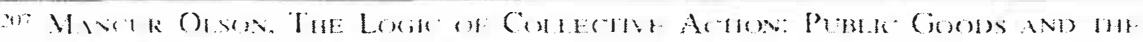

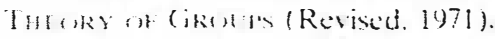

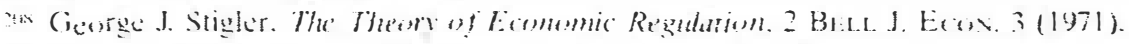

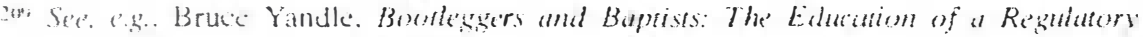

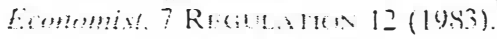

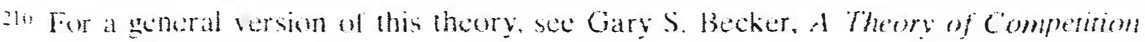

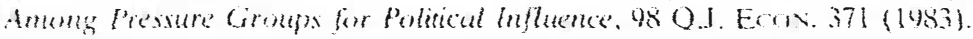

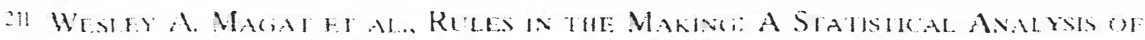

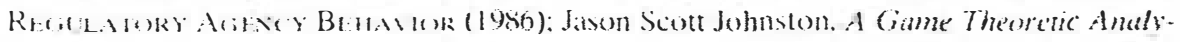

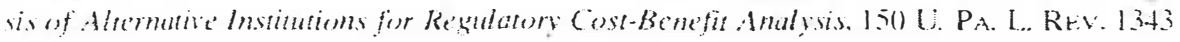
$(2(1)(1))$ 
crete, well defined, and active interest group. ${ }^{212}$ However, if an accident (e.g. an environmental disaster) were to happen, the shadow interest group would cease to be a shadow group and become active and thus have all the characteristics of a normal interest group. Knowing that shadow interest groups have the potential to become an effective lobby, rational politicians will respond to these groups in the same way that they will respond to normal interest groups, even though the shadow groups have not organized. ${ }^{213}$

In applying this general approach to develop a positive theory of regulatory centralization, the first and most important thing to recognize is that it is not environmental regulation that is to be explained but rather the centralization, or federalization, of environmental regulation. Even if environmental regulation may be seen as a paradoxical triumph of diffuse, unorganized interests. centralization may be easily explained as arising when there are large economies of scale and a generalized, majoritarian preference for reduced pollution. ${ }^{21+}$ That is, if the majority of voters favor reducing pollution, and they have (for whatever reasons) the political power to get such pollution reduction laws passed, and if there are potential economies of scale in environmental regulation, we should expect eventually to see pollution reduction pursued by the cheaper, federal provider.

However, this story is much too simple and sanguine. In both Europe and the U.S., centralized environmental regulation has generally meant the imposition of minimum standards for pollution reduction. For at least some jurisdictions, both within Europe and the U.S., such minima are binding in the sense that they require more pollution reduction than the jurisdiction would require on its own. Moreover. as we recounted above, in both Europe and the U.S. centralized environmental laws are more concerned with controlling pollution that has primarily local, intra-jurisdictional impacts, rather than pollution that has clear transboundary effects.

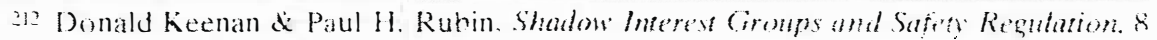
WTI RFV. L. d EOON. $21119 \mathrm{sir})$.

$213 \mathrm{ll}$

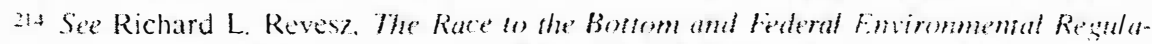
tion: A Response te Critics. $82 \mathrm{M} \mathrm{NN}$. L. Ri. . $535(1997)$ farguing that the logit of collective action suggests that underrepresentation of environmental groups would he more serious at the federal level since they face larger scale free-rider problems and a loss of homogeneity of environmental interests at the federal level): we also Richard I. Revesz.

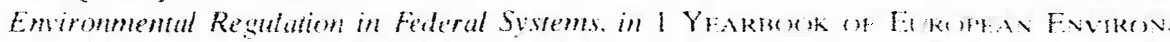
WH NAL LAW. supra note 157, at 1. 
Thus, the goal of the positive economic analysis of environmental federalism is to explain what may be called the Paradox of Environmental Federalism: the imposition of uniform federal standards for the reduction of localized pollution on sub-federal jurisdictions who actually had quite different preferences for environmental protection versus development, and who would therefore have likely had widely varying standards for pollution reduction under decentralization. There are several potential economic explanations for this Paradox, and it is to these that we now turn.

\subsubsection{Development and the Demand for Environmental Protection: The Convergence Thesis}

The positive paradox of environmental federalism rests upon an assumption, namely that different sub-federal units would indeed demand different amounts of pollution reduction. thus making uniform federal standards binding on at least some jurisdictions. The underlying question is whether the establishment of lederal minimum pollution standards simply hastens something that would occur in any event: the convergence of environmental standards as a consequence of converging levels of economic development and income. The idea here (essentially the same as that behind the socalled environmental Kuznets curve $)^{21.5}$ is that there is little demand for environmental protection at low income levels and high environmental yuality, but as income and pollution increase as a jurisdiction industrializes, eventually the jurisdiction achieves an income level and corresponding willingness to pay for environmental protection, such that the jurisdiction requires cleaner technologies to be used. On this theory. per capita pollution falls beyond some threshold level of per capita income. ${ }^{210}$ In terms of

2s The corvironmental kiznets curse is the cimpirical cross-country relationship. shserved for several important pollutants, in which per capita or total emissiuns first rise and then fall with national per capitat income. For an overviews see S. Daseuptat et al.

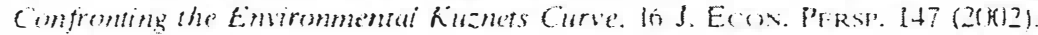

in There are various mixes of demand push and technology supply that con generate such an inverted $V$-shaped relationshup between per eapita income and per-capita pollu-

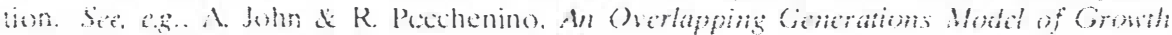

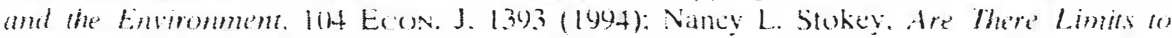

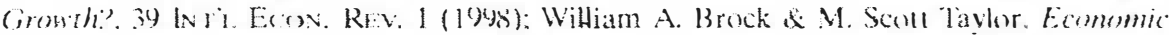

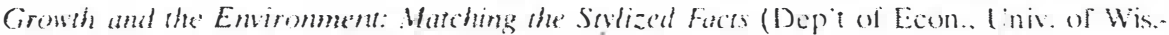
Madison, Worting Paper No. 16. 2(0)3). For the original work suggesting such an inverled $V$-shaped relationship the environmental kuznels curyes. see (jene M. (iroxeman \& Alan

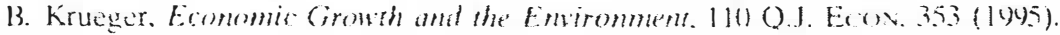


regulation, beyond some point, the wealthier a locality becomes. the more stringent its pollution control requirements will be.21?

\subsubsection{Federal Level Majoritarian Politics}

The evidence from the United States reveals that two factors drove the great 1965-1975 period of American environmental federalization: new, income-driven demand for pollution reduction in the wealthiest and most heavily developed states, and growing divergence between developed and less-developed regions in terms of both per capita income and pollution levels. ${ }^{218}$ How then to explain the imposition of federal minimum standards?

The simplest explanation relies on majoritarian politics. Assuming a very general distribution of preferred ideal levels of pollution control between states with low. medium and high levels of demand for such controls (where demand is eyual to the preferred point of the state's median voter), a federal minimum standard equal to the ideal level of the moderate jurisdiction will always achieve a majority. Also, since it is a minimum, it does not bind the high-demand states from regulating even more stringently. ${ }^{21}$, This is a strikingly simple but powerful result. It shows that there will be majority support for federal minimum standards even if there are no inter-jurisdictional externalities that would justify such federalization. Or. as Crémer and Palfrey put it. that such "exeessive interference" at the federal level is a "normal" consequence of the behavior of voters and a probably unavoidable feature of federal systems. Local political fights have tendency to spill over at the federal level. as voters will try to have their preferred policy imposed at both levels of government."

2: Grosman \& Krueger supra note 216: Brock \& Tivkor supra mute 216.

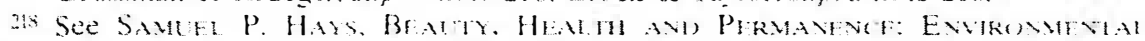

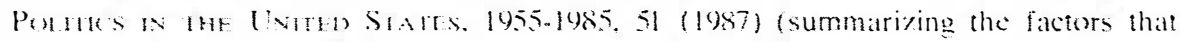
accounted for l970's environmentalism and its regional diflerences).

2:" For a formal demonstration that this equilbrium holds both when the standard is shosen by a lederal referendum and when is is chosen be lederal representatives who wote the preferences of the median voter in their jurisdiction. see Jacques (remer \& Thomas $R$.

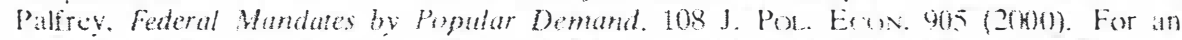
extension to consider the impict of lexal political processes, sec Jiteques (remer of thomat

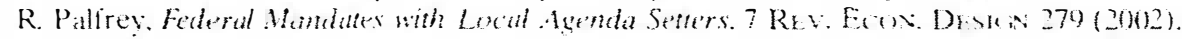
In an carlier paper. Cremer and Palley show that centratization is virtually certan if voiers are rist averse and have better information ahout the federal median voter than ahout the median voter in their jurisdiction, and federal poliey is determined by ventes among jurisdictional federal legislators who represent the preferences of the median woter in the ir jurisdictions. Jacgues Crémer de Thomats R. Palfrey. In or Out? (entralizatom by Majorion

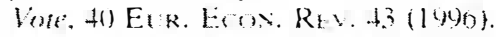

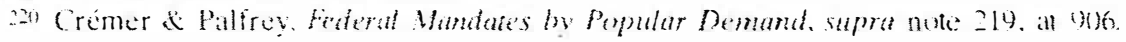


Although this model is positive - it explains federal-level majority support for federal minimum pollution control standards - it hats normative implications. Note that while a system of fecteral minima leaves some voters worse off than they would be under a state-law system (e.g. low demanders in jurisdictions with low median (emand), it also makes some voters better off (e.g., high demanders in jurisdietions with low median demand). Becaluse the federal standards are too high for a substantial proportion of voters in low-clemanding jurisdictions. even if federal standards provide economies of scales or help to reduce interstate externalitics (by reducing pollution that spills over from low-demanding states inte higher-demanding states), it may still generate a net welfare decrease relative 10 decentralized provision.".

\subsubsection{Federal Mandares as Regional Indurtad Protectionism}

The model of Crémer and Palfrey explains majority support for federal environmental standards set at a level preferred by mederate jur isdictions and also explains who might bencfit from such standards (namely. environmentalists who live in places where there is litte lecal demand for pollution reduction). However as public choice theorists have pointed out. during the U.S. environmental era some firms and industries also supported environmental regulation. Such support exemplifics another important driver behind federalization: the desire of older, more heavily developed and polluted jurisdictions and industries with large sunk investments in such places) to use federal mandates to lesien the competitive advantage of less heavily developed and less polluted jur isdictions in attracting new industrial piants and jobs. By kessning the competitive advantage of relatively pristine. unpolluted jurisdictions, fecteral ensirommental mandates may serse as an instrument of industrial protection for older. heavily polluted jurisdietions. For these reasons, the median voler in

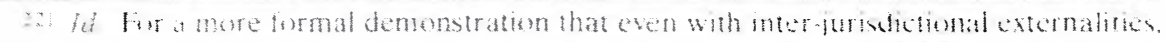

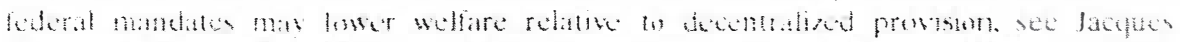

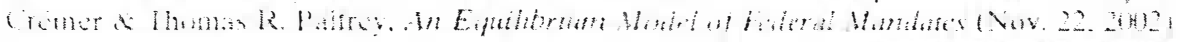

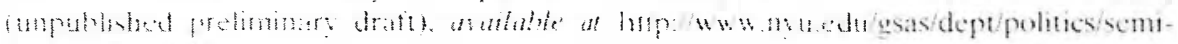
mars paltreypdi.

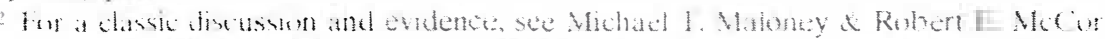

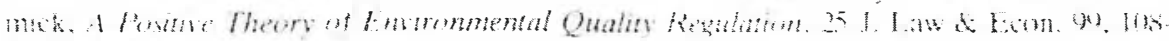
$11711 \times 2)$

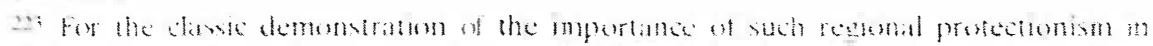

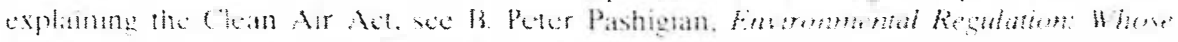

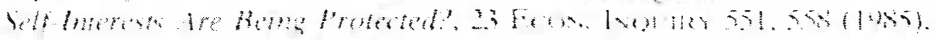


wealthier, but more heavily polluted jurisdictions (Germany in Furope. New Jersey in the U.S.) may well prefer tough environmental standards. Using federal mandates to require more pollution reduction than is locially desired in poorer, hut less polluted jurisdictions (Spain or Greece in Europe, Georgia or Alabama in the U.S.) is a way to lessen the comparative disadvantage of tough pollution standards in the high demanding jurisdictions.

\section{2.t. Finvirommenal Federalization. Political Symbolism und Political Discretion}

As we described earlier in our discussion of the stylized facts of European versus American federal environmental regulation. in hoth the U.S. and Europe, centralized environmental mandates often contain very vague but also very ambitious goals. For instance. the U.S. Clean Water Act still declares national goals of "zero discharge" of pollutants into the "waters of the Enited states." and of making all those waters "lishable and swimmahle.".2! Such statutory goals are often criticized als unrealistic. Yet they have a powerful underlying political logic that is important in understanding environmental federalization.

The logic is this: pollution reduction by an industry or large numher of firms may confer large aggregate benefits in the form of better health outcomes, improsed recreational opportunities and perhaps atso improved ecosystem health. but those benefits are typically very widely diffused and so may he individually small. This is especially true with regard o inter-jurisdictional pollution. The costs of pollution reduction, by contrast, are typically concentrated in particular firms and industries located in particular states and regions. Hence, while there is clearly an incentive for feckeral politicians to please voters who will henefit from pollution reduction. (hey may also represent particular geegraphic districts in which constituents will sulfer ery real costs from pollution reduction. Such politicians woukl have every incentive $u$ pass legislation that sets up broadly popular pollution reduction goals, but which shifts the responsibility to other governmental branches sub-national govermment or federal regulators - to actually implement those goals through pollution standards and plant-specitic permits that impose economic costs on firms. industrics and communities. Such a system - broad and ambitious statutory pollution reduction goals, implemented by regulators and sub-national gov- 
ernment - gives legislators the ability to say that they have acted for the environment, while also reserving to them the discretion to intervene in the regulatory process by lobbying against regulations that will be too costly for their geographic constituents. 22.5

A number of stylized facts about both U.S. and European centralized environmental law confirm this model. First, and notably, it accords very closely with the very important role that American presidential clectoral politics seemed to play in driving forward the great Environmental era federal environmental laws.226 Second, it explains very well why the United States Congress chose to delegate so much implementation and enforcement responsibility to the states: by so doing, Congress maximized political support while taking account of the fact that the actual costs and benefits of federal environmental standards vary greatly from one place to another. 227

A similar story could be told about Europe as well: the key player in the European legislative process, the European Commission, can make itself popular with widely supported pollution reduction goals. As discussed hefore, it is the European Commission that takes the initiative on European legislative measures such as environmental directives. The actual implementation of the broad goals formulated in a directive will subsequently be done at the national member-state level, since the directive will have to be transposed into member state laws. Typically the members of the European parliament are "greener" than the environmental ministers in the Council. The elected members of the European parliament may thus have an incentive to promulgate directives that call for Europe-wide improvements in environmental quality. while leaving implementation and regulatory measures to the Member States" national legislatures.

2.5 This model. which relies heavily on the work of political scientist ferry Moce is set out in Johnston. A Ciame Theoretic Andysis of Alternatie Institurions for Regulatory costBenefit Alualysis. supra note 211.

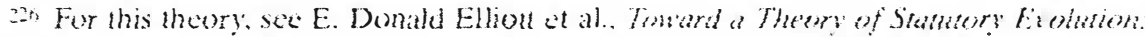
The Federatization of Envirommental Law. I J.L. Exon \& ORs. 313 (I9S5).

22 For this explanation of cosperative leckeralism in environmental regulation. see Jonathan R. Wacev. Feteral Deference to local Riguaters and the Eionomic Theorv of

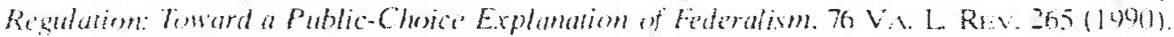


4. Explaining and Evaluating European vs. U.S. ENVIRONMI:NTAI. LAW IN Light OF POSITIVE AND

Normative ECONOMIC ANALYSIS OF

Ri:guiatory Centralization

\subsection{Is the Normative Case for Environmental Centralization Stronger in the U.S. or Europe? Some Suggestions and Questions}

While Europe continues to move toward fuller economic integration, the United States remains much more fully integrated economically, culturally, and politically than its European counterparts. American regions do retain some distinctive cultural features, ${ }^{22 x}$ and residents in different regions vary greatly in the value they place on the environment. ${ }^{229}$ Still, there are virtually no barriers to capital mobility within the United States. While there are a few barriers to labor and residential mobility, both are relatively high in the U.S. as well, and American states and localities actively compete in offering varying packages of jobs, living standards, and environmental and non-environmental amenities. In Europe. by contrast, although capital has become much more mobile than it was prior to the Maastricht Treaty (Treaty on European Union) of 1993. ${ }^{2 * 1}$ labor and residential mobility remain lower than in the U.S. ${ }^{231}$

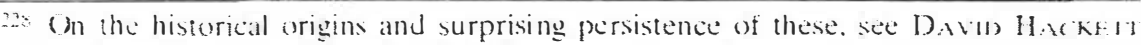

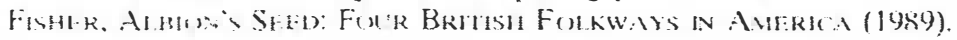

‥ See the discussion of regional differences in environmental concern and activity during the 1970.s by Hass supra note 218. at $4.3-51$.

ai: For a discussion of the measures taken during the $190(1)$ is $t 0$ open up capital flows by ihe countries of Southern. Central and Eastern Europe, and their effects. sec Claudia M.

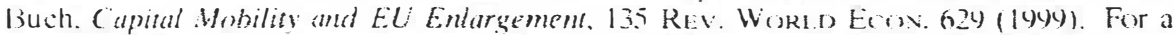
case study of Poland. where FDI increased over tenfold during the 1990's. see Boleslaw 1)omanski. lipes of Intestment and focutional Preferences of European, American and

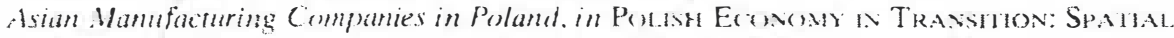

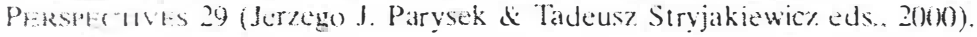

231 As for residential mobility. One study finds that Americans move nearly twice as olten as Dutch. French. (icrmans or Norweggians. W. Paul Strassman. Housing Market

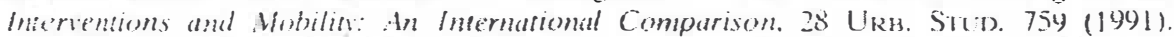
Economists have long argued that highly persistent wage dilferences and relatively high unemployment indicate that high harriers to intra-European labor mobility continue to sist. See Olivier fean Blanchard de Lawrence F. Kat\%. Regional Evolurions, in 1 Bkomk-

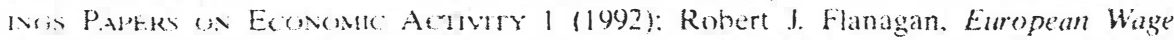

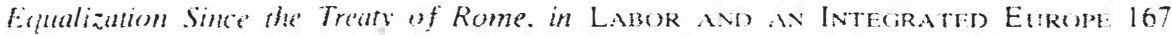
(Ljoyd Ulman et al. eds.. 194.3): Michat Fertig de Christoph M. Schmidt, Mobility Wirhin

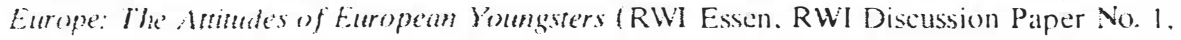
2(1) 2$)$. 
From the point of view of normative economics, these various factors combine to paint a rat her complex picture. Because capital mobility is lower within Europe than in the U.S., there is less reason to fear a regulatory race-to-the-bottom within Europe, and therefore - other things being equal - less justification for environmental regulatory centralization in Europe than in the U.S. On the other hand, because residential and labor mobility is so much lower within Europe than in the U.S., there may be less reason in Europe to trust in Tiebout-type inter-jurisdictional competition disciplining sub-federal governments to provide the level of environmental amenities favored by the median voter. There may well be significant variation across European nations in voters' preferences over environmental versus non-environmental public goods, but there is also substantial variation across U.S. regions in voter preferences for environmental public goods, variation that is ignored. or rather overridden, by uniform federal environmental standards.

Of course, both Europe and the U.S. are changing. When the great federal environmental laws were passed, there were large differences in the level of economic and industrial development across American regions. Those differences have narrowed significantly. In particular, between 1970 and 199(), the heavily industrialized Northeast and the Midwestern "Rust Belt" have actually become more rural, while the South and Rocky Mountain West have become more urban. 232 Given the systematic tendency for ambient levels of air pollution to be significantly higher in urban versus rural areas, ${ }^{23}$ and due to their increasing urbanization, the once relatively rural and under-developed Southern and Rocky Mountain areas have come to experience pollution problems that they did not have when the federal environmental laws were passed in the early 1970's. Ironically, perhaps, while uniform federal environmental standards may have suppressed large regional

$\therefore:$ The pereentage of the population living in rural areas in the Northeast increased from 19.4\% $1021.1 \%$ over the $197(1-199()$ period, with a smaller increase. from $25.2 \%$ to $26 \%$. in the "rust-helt" (east north-central) area: hy contrast, in the south. the rural per" centage fell from $35.2 \%$ in $19701031.4 \%$ in 1990, with an even higger tall, from $20.9 \% 10$

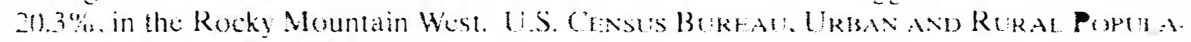

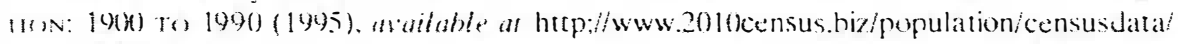
urpepixisitixi.

23.3 For a recent study comparing ambient levels of fine particulate pollution in rural, urban (and background, national park) locations that tinds much higher levels in the urhan area in the fall and winter. due to carbonaceous aerosol particles in the urhan airshed during those seasons. see Roger L. Tanner et al. Regional Composition of PM: Acrosols Weavired at Urban, Rural and "Batkground" Sites in the Tennessee Valley. 38 Atwos. MHERI ENVT 3143, 3147-4is (2m).4). 
differences in preferences in 1970, regional preferences may now be much more similar, so that in the U.S., the case for uniform federal environmental laws may be much stronger now than it was when these laws were passed thirty years ago.

In Europe, enlargement of the EU has resulted in the application of uniform European pollution standards to countries at radically different stages of economic development. During the early and mid 1980's, when EU environmental policy exploded in hundreds of pieces of environmental legislation, there were significant cross-national differences in levels of industrial development and pollution, but enlargement of the EU since the Maastricht Treaty has vastly increased those differences. ${ }^{23.4}$ The welfare conseyuence of having uniform European environmental standards apply to such very different places depends upon the answers to a number of questions: How similar are the environmental preferences of people in Poland or Slovakia, for example, to those of people in Germany and the Netherlands? What are the ambient levels of pollution in such very different countries? To what extent would national governments in the newly acceded countries act to regulate environmental pollution in a way favored by the median voter? To what exten thas increased capital mobility within the EU made the race-to-the-bottom a real concern in the new and enlarged EU? Answers to these questions will be crucial for the normative evaluation of future EU environmental policy.

\subsection{The Paradox of Centralized Environmental Regulation for Local Environmental Problems}

What we take to be the great paradox raised by both American and European centralized environmental regulation is this: whereas perhaps the primary economic motive and justification for such centralization is the need to better regulate inter-jurisdictional pollution, in reality both the United States' and Europe's centralized environmental regulations are directed at primarily local pollution problems - that is, pollution that does not in lact spill over across state lines. Moreover, where very basic cost-benefit economics would dictate varying pollution standards -- with less devel-

23. In $(9)()$. for example, per capita income in highly industrialized formany was ahout $5.5 \%$ higher than in less-industrialized Greece. In 1999 . German per capita income was $250 \%$ that of per capita income in Poland. Hermine Vidovic. Synthesis of Re'e'm Labour

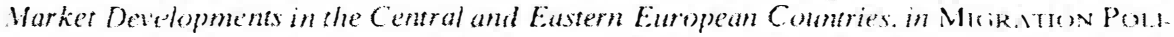

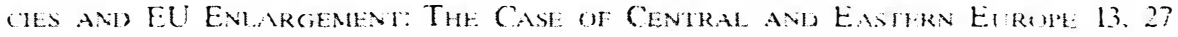
(2001). 
oped. less polluted places allowing more pollution (because damages from pollution are less) and more heavily polluted places having tougher standards - U.S. federal and European centralized environmental regulations generally require uniform pollution reductions, regardless of local costs and benefits. How then to explain the emergence of such inefficient uniform centralized standards?

\subsubsection{The Choice for Uniform Technology-Based Emission Standards: Regulatory Protectionism in the EU vs. the U.S.}

As discussed in Section 3, a powerful positive force behind uniform central environmental standards is the industries and governments of heavily developed, heavily polluted jurisdictions. For industrialized, polluted jurisdictions, the imposition of uniform emission standards upon less developed jurisdictions is a way to lessen the competitive disadvantage they face from cleaning up their own pollution. and therefore constitute a form of regulatory protectionism.

There is powerful evidence of regional protectionism in a number of American federal environmental statutes. This theory finds dramatic supporting evidence in the Prevention of Significant Deterioration (PSD) provisions of the U.S. Clean Air Act Originally implied into the Act by the U.S. Supreme Court and subsequently included in the 1977 Amendments. the PSD provisions impose air pollution control standards on those regions of the U.S. that already meet the national ambient air quality standards and which therefore could, were it not for the PSD provisions, allow new industries to locate within their borders and pollute at will without violating national standards. ${ }^{23}$ As Pashigian has demonstrated in his classic study of the PSD provisions, the imposition of such federal mandates on relatively pristine and unpolluted regions of the U.S. was a major goal of federal legislators from the older and more heavily polluted U.S. states and legislative districts. 23

$2 \$ 42$ U.S.C. $\$ 7+70-42(200())$.

236 lal.

2.37 B. Pater Pashigian, Environmental Regulation: Whinge Self-Interests the Being Pro. tected? supra note 223: see also Richard L. Revesz. Federalism and Envirommemal Regulation: A Public Choice Analysis. 115 HaRv. L. Rev. 553 (200) 
Similarly, in Europe, there have been a number of instances in which industries ${ }^{23 *}$ in heavily industrialized and heavily regulated countries such as Germany and the Netherlands have lobbied for the EU to adopt their own tough national standards as EU standards, so as to ensure that they are not placed at a competitive disadvantage relative to industries in less heavily regulated EU countries such as Spain. ${ }^{234}$ In 1983. Germany enacted its Large Combustion Plant Regulation, a technology-based law setting stringent limits on the air emission of sulfur dioxide and nitrogen dioxide from new plants and requiring retrofitting of existing plants. ${ }^{2+1}$ Only after passing this tough domestic law did Germany begin to actively pressure the EC to adopt a directive requiring that German standards be met throughout the EC. These efforts succeeded in 1988. when the EC issued a directive on Large Combustion Plants to require country-specific reductions in air emissions. ${ }^{2+11}$

Another example of such interest group behavior is the European Directive on Integrated Pollution Prevention and Control (the IPPC Directive). ${ }^{2+2}$ Had this directive aimed to achieve a harmonization of ambient environmental quality across Member States facility-specific emission limit values would have had to differ from one country to the next to meet location-specific circumstances and still achieve a similar level of environmental quality. Such a directive would have been to the disadvantage of industries in countries that already had strict facility-specific enissions limits. such as Ciermany. Precisely as predicted by this analysis. in the negotiations leading to the Directive, industries in heavily regulated countries such as Ciermany and the Netherlands opposed an ambient environmental quality-based approach. while those in countries with systematically different hydro-geological conditions.

In in addition. green NGOs will be pleased with this lobhy and often support the demand to transfer strict national standards 10 a European standard. Davis Vixiti.

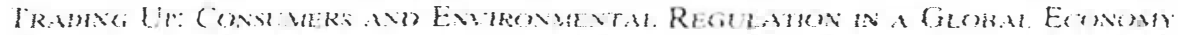
$52-55(1995)$

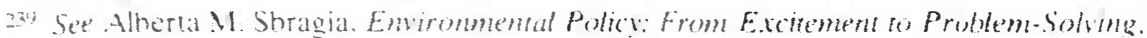

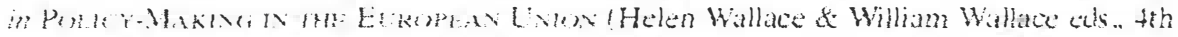
(6) 1946) (cited and discussed by Jordan. supra note (1)5).

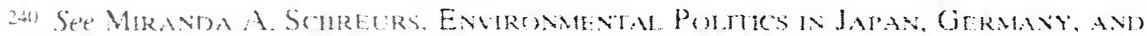

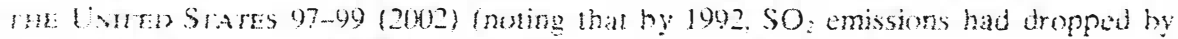
more than 75 percent of 1970 levels in the former West Germany).

$2: 1$ see il. at 101 .

24: The IPPC: Directive supra note 81. Se also Faure \& Lefevere supra note 86: Wichat Faure \& J.G.I. Lefevere, The Drafi Directive on Integrated Pollution Fretention and Conrol: An Economic Perspective. 5 Elk. ENit1. I.. REv. 112 (1996). 
such as the UK, favored such an approach. ${ }^{2+3}$ As with U.S. federal environmental laws, interest groups in more heavily industrialized and heavily regulated countries have generally prevailed at the European level, with the IPPC and other European directives providing for the harmonization of emission limit values rather than ambient environmental quality standards. ${ }^{2+4}$

Political scientists point to the fact that the EU parliament is largely in favor of strict detailed laws as a tool to constrain the Member States. ${ }^{2-5}$ The reason is that Member States distrust each other and worry that some may not implement environmental directives effectively. ${ }^{2+1}$ That is also why Member States, via the Council of Ministers, favor increased authority for the Commission to take action before the ECJ against Member States that fail to implement European environmental law appropriately. ${ }^{2+47}$ Looking at the economic criteria for centralization presented in Section 3 of this article, one gets the impression that the fear of other Member States not adequately implementing envirommental directives. thereby creating a competitive advantage for their economies, is an important motivation behind support for strict, precise rules in directives that restrict Member States discretion, as well as the propensity for strict and increasing actions against Member States that lag behind in implementation.

The political-economic story that has played out in Europe over the choice between uniform, industry-specific emission limits versus ambient environmental quality standards is thus very similar to that which has occurred in the U.S. One may question. however. whether the game had quite the high stakes in Europe that it has had in the U.S. In the U.S., there is a federal regulatory agency, the EPA backed by the U.S. Department of Justice, which is in a position to take over the job of both writing and enforcing facilityspecific permits that implement nationally uniform, technologybased pollution standards. In Europe, there is no comparable European-level regulatory agency with the police power to conduct

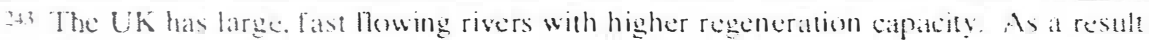
the Uk may not need as stringem emission limit values as. for exampls. Germany foreath a similar emunommental quality.

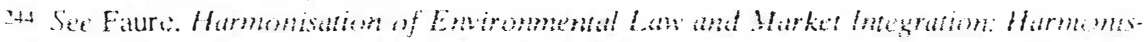
ing for the Wrong Reasmes? supra note 102. at 17t. Another example is the lest directive on large combustion plants and acid rain that was strenuously sough by Dutch and fiorman industry. Sé Jordan. supra note 105 , al lis.

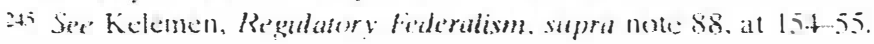

2 to $\mathrm{Id}$.

- $-4: 1,1$ 
facility-specific inspections and then undertake enforcement actions in court. For this reason, even facility-specific emission limits may not really help polluters in the most heavily regulated European countries, since the enforcement of those standards in less heavily regulated countries is ultimately in the hands of domestic, rather than centralized European enforcement authorities..$^{2.45}$ Hence, it may be that the desire of the more heavily regulated Member States for such site-specific standards may well be something done in the expectation of the future development of a centralized. European environmental regulatory agency with full enforcement authority. Moreover, one can also understand that it would particularly be the more heavily regulated Member States that would lobby for stringent enforcement of European law at the Member State level.

\subsubsection{Environmental Regulatory Centralization as an Inevitable Consequence of Divergent Development in Majority- Rule Federations}

Recall that in the model of Crèmer and Palfrey, federal minimum standards are a more or less inevitable consequence of majority rule in a federal system where jurisdictions can be arraved as low. medium or high demanders of the public good in question. In both Europe and the U.S., centralized environmental regulation was a product of precisely such majority-rule le islative politics. and in both places, centralized regulation arose when the relevant jurisdictions were indeed quite diverse in their preferences for environmental protection. Hence we believe that one part of the answer to the apparent paradox of uniform centralized environmental minimum standards for essentially local environmental problems is quite simple: because those minimum regulatory standards were what the median jurisdiction wanted, they were the majority-rule choice in the central legislature.

In the United States, for example, when the major federal air and water pollution minimum standards were enacted in the carly 1970's. there were vast differences in average wages, incomes, and general levels of development between different national regions. with the Southeast and interior West still trailing far behind the older, more developed Northeastern. Midwestern and Pacific Coast regions. On an aggregate level, the evidence does indicate that the peak years of the American environmental movement.

ins ld. al 150 . 
from 1965 to 1975 , may well have been a very special time. It was a period when the accumulated environmental degradation caused by rapid postwar industrial growth became strikingly obvious, and when per capita income in the more developed regions of the country had reached the threshold level where the willingness to pay for pollution reduction was sufficiently high to generate a demand for tougher environmental regulations. ${ }^{249}$

There were striking inter-jurisdictional differences in willingness to pay for pollution reduction when the American federal environmental laws were passed, however, and those differences have persisted to a perhaps surprising degree. Overall, the existing evidence from the U.S. shows that beyond some threshold income level. state-level demand for pollution control does increase. But the evidence also indicates that per capita income alone does not fully explain interstate variation in pollution. For sulfur dioxide $\left(\mathrm{SO}_{2}\right)$ emissions, there appears to be a clear inverted $\mathrm{V}$-shaped relationship, with two categories of U.S. states: those with low to middle income, where $\mathrm{SO}_{2}$ emissions increase with economic growth, and high income states, where pollution begins to decline. ${ }^{250}$ But income alone does not account for interstate variation. Within the set of rapidly growing states, emissions of nitrogen oxide and sulfur dioxide have peaked at quite widely varying per capita income levels. ${ }^{25}$ Although they have grown rapidly since the 197()'s. a disproportionate number of Southern states have passed state laws that forbid state environmental standards that are tougher than federal minima. Whether such interstate heterogeneity is due to differing degrees of urbanization, climate, or unobserved cultural factors remains to be explained.

A similar trend describes similar regulation in Europe: most environmental regulation in the Western European states only emerged after the "golden sixties." The early sectoral environmen-

2+1" Se' John A. List. Have Air Pellume Emissions Converged Among L.S. Regiems.?

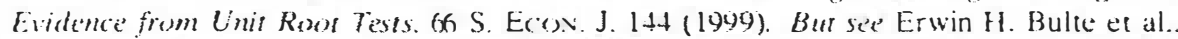

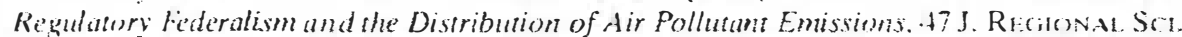
$155(2 n) 7$ ) (suggesting that convergence occurred only after the passage of federal laws).

250 Vektarios Aslanidis de Anastasios Xepapadeas. Smooth Transition Pollution-Income Pulh. 57 Ecolocilcal, E(t) . 182. 187 (2006).

251 John A. List \& Craig A. Gallet. The Environmental Kuznets Curve: Does One Size Fit All?. 31 Ecolocilcal E(oN. 409. 420 (1999) (showing very different turning points in per capita emissions for Texas. Arizona and Colorado). In addition, there is evidence that in the United States, state level emissions per capita of sulfur dioxide and nitrogen oxide tailed to converge until the passage of the federal Clean Air Act. Bulte et at.. supra note 249. The problem with this study is that theoretically, what is predicted to converge is emissions relative to per capita income, not emissions relative to per capita population. 
tal laws (aiming at protection of. for example, surface waters) in countries such as Belgium, Germany, France, and the Netherlands date from the 197()'s. ${ }^{252}$ During that period, economic development had apparently led to such a level of wealth that a demand for environmental protection was generated. Economic development in Southern European nations was, due in part to political instability (for example, in Spain and Greece), still falling far behind. Only when the level of economic wealth in the southern states increased substantially. as a result of joining the European Union among other things, was a demand for environmental protection generated. (Of course, these nations were also forced to implement environmental protection as a result of the EU's directives).

We expect a similar pattern for the new Member States of Central and Eastern Europe, where the top priority may be economic development. As a result, the demand for environmental protection measures is likely low, and thus any attempt by the European Commission to force these new members to augment environmental regulation may be fraught with difficulty. However, one can equally expect that as the new Member States develop, there will be a parallel increase in demand for tougher environmental regulations. Alternatively, there may be an increased willingness within the EU context to implement environmental directives more seriously.

\subsection{EU Enlargement as a Natural Experiment in the Logic and Limits of Environmental Federalism}

The enlargement of the EU may provide a natural experiment to test alternative positive theories of environmental regulatory centralization. One's first thought might be that the addition of relatively less developed nations such as Slovakia and Poland countries with relatively cheap and abundant land, labor and other inputs to the production process - would heighten the protectionist motive for environmental regulatory centralization. But such a conjecture depends upon the implicit assumption that cheap resources would confer a competitive advantage upon firms based in countries such as Poland, as they competed against firms based in wealthier, more industrialized countries such as Germany and France. This assumption treats the new Central and Eastern Euro-

252 See Pliblo Envikonmental Law in the Elikopean Union and the Livted Stales: A Comparative ANAlysis, supra note 2. 
pean EU members to be more or less akin to the Southeastern stittes in the U.S.

We do not yet have evidence with which to analyze this thesis. While it does seem as if capital is increasingly moving from older. developed EU countries into the new Member States - thus threatening joh loss and dislocation in the older. developed countries - it does not appear that there are actually new. competitive firms forming in the formerly communist nations. Capital mobility in Europe - in particular between Eastern and Western Europe - has increased spectacularly, ${ }^{253}$ although the direction is certainly not always from West to East and the reason is mostly not environmental. There is for example, the well-known phenomenon of increased lahor migration from Eastern European countries (like Poland) to Western European countries (like Belgium and the Netherlands). ${ }^{-44}$ and there are similar stories of Western European companies moving to the East. Before the enlargement. there were already large foreign direct investments in Eastern European countries After enlargement, this process has of course increased, and it takes a variety of forms: for example. Dutch transport companies installing themselves in Eastern Europezon and German chemical companies investing in Eastern Europe. Indeed. Western European fïms (as well as American and Asian ones) are investing in new plants and facilities in the new EU nations.

However. the reasons as advanced by industry for this move towards Eastern Europe are mostly related to lower taxes and labor costs. Average labor costs in the new Member States chemical inclustry are only 5 euro an hour as opposed to 27 euro among current EU members." However, the run to EU membership atready spurred investments in technology to facilitate compliance

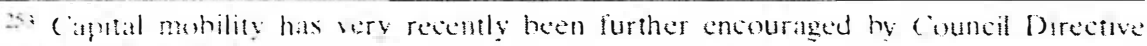

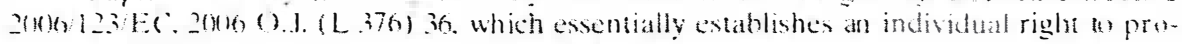
rike serves in any mamber stite of the Lnien.

is Wurkers from Easkern Eurupe in Belgium are especially active in the hulding sector, which has led w concern about "unlair competition" among trade unoms in Belgitum. Ste"

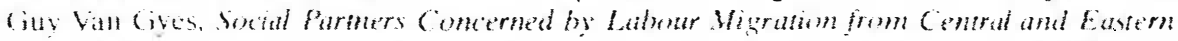

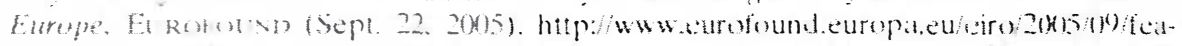
ture helish)

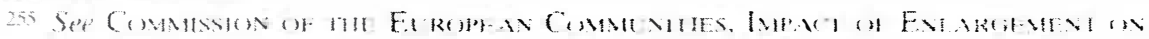

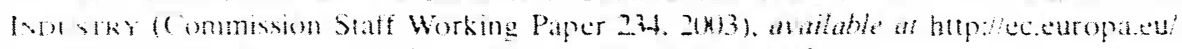

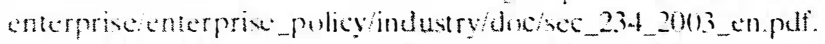

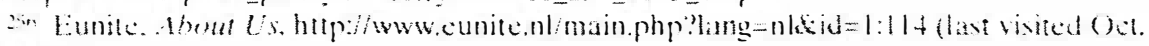
(i). 2nkil.

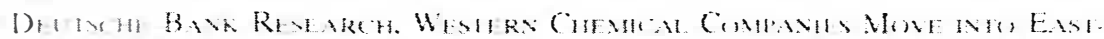

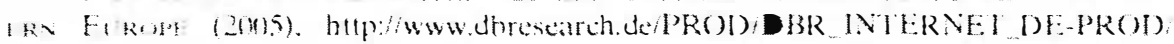

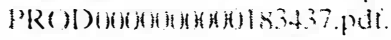


with environmental regulations. Hence, a recent Deutsche Bank research report argues that the increase in environmental standards has proved a handicap for the chemical industry in Eastern Europe, which explains the increased investments by the German chemical industry in the new Member States. ${ }^{258}$ Such firms would, if anything, have an incentive to favor environmental regulatory decentralization, so that they can take advantage of lax environmental standards in new Member States with slower development. The question is whether enlargement has indeed led to such a weakening of standards. Such a weakening could occur either through formal exceptions granted by the EU Commission for the "environmental acquis" 25 " to new Member States, or through lenient enforcement. There is however, little evidence of formal exceptions. There are some exceptions in the Accession Treaty, but most of these relate to issues such as free movement, not to environmental issues. ${ }^{2+0}$ The environmental acquis is therefore. in principle. applicable to new Member States as well. Moreover, many new Member States had a long transition period to adapt their legislation to EU norms before formal accession. Today, at

\section{2. $l$ ld.}

25" The "uniromental acyus" refers to the bexty of European environmenal late which is in existence and in that sense "acquired."

26) Sete e.g. Treaty conceming the Accession of the Republic of Bulgaria and Romania wo the Europeat o Enion. June 21, 20)(15.20050.3. (L 157) 11. The principle of accession can be illustrated by examining the Act conecrning the conditions of atecession for the crech Republic, the Repubtic of Estoniat the Republic of Cyprus, the Republic of Latwa the Republic of Lithuania, the Republic of Hungary, the Republic of Malta. the Republic of Poland. the Republic of Slovenia and the Slovak Republic and the adjusments to the treatties on which the European Lnion is founded (official journal. Sept. 2.3. 20013). Article 2t of this Act refers to measures lised in annexes which state that they only apply to the new Member States under the conditions laid down in those annexes. Voreover. Part 5 provides provisions relating to the implementation of the set. The principle. as emboded in Article 53 . is that upon accession. the new Member States shall he considered as heng addressees of directives and decisions within the meaning of Article 249) of the treaty. which means the new Member States have to comply with existing directives (the so called Acquis (ommunataire) in principle. A long list of annexes (one for esery Member state:) then provides specilic exceptions. For example. annex $V$. related th the Czech Republic. states that the articies of the treaty concerning the free movement of workers and of provision of services only atpply subject to traditional provisions latid down in paragraphs 2 to 1.4 . Note however that the only effect of the exceptions for the new Vember states is that it concerns the timing by which they have to comply with the environmental acquis. Ihe exceptions are in other words. simply transition periods that allow the new Member Stats to take a longer ame to get used to the requirements under the ensironmental acquis. For example. as far as industrial pollution control and risk management are concerned. annex $\checkmark$ provides that the Crech Republic only needs to comply with a specific directive by December 31. 2(x)7 regarding emissions limits of certain air pollutants from large combustion plants. Similar exceptions (transition periods) are provided for specific plants lor the other accession countries via specifie directives. 
least formal norms are not less stringent (as far as EU environmental law is concerned) in the East than in the West.

Leniency for new members could also arise in the field of enforcement. However, work by Börzel, as well as a recent annual survey of implementation and enforeement of European Community environmental law in 2()(5). show that proceedings are equally instituted against old and new Member States, both for non-communication infringements and for non-conformity infringements. ${ }^{2+1}$ Remarkably, it appears to be the old Member States (such as France and I taly) that top the list as far as infringement proceedings are concerned. However, one must always be careful in interpreting these numbers: even if there were formal implementation of EU environmental law in all new Member States (which would explain why they are not confronted with more cases than against the older fifteen states). one has to keep in mind that the EU can only control the formal implementation. i.e., whether national law complies with EU environmental directives; it is much harder for the EU Commission to control whether environmental laws are effectively enforced. ${ }^{22}$ It is also harder to measure. In our view, a crucial question for further research is the extent to which there is actual uniformity in the national enforcement of EC environmental directives that have been formally implemented in national law.

Moreover, unlike the era of environmental regulatory centralization - when heavily developed jurisdictions in hoth the U.S. and Europe were also heavily industrialized. with many relatively labor-dependent industries - many of the wealthiest and most proenvironmental European nations have already shifted away from labor-intensive production. It is neither Germany, nor the Netherlands that face a threat from the cheap labor and resources offered by new Central and Eastern European Member States. but rather Spain. Portugal, and Greece, ${ }^{26.3}$ countries whose industries actively compete in labor-intensive areas where the new EU members also

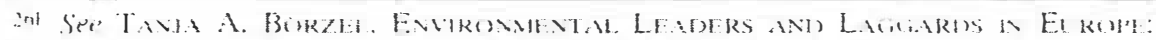

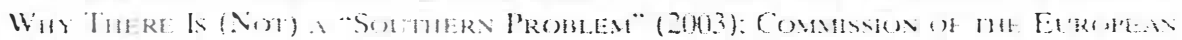

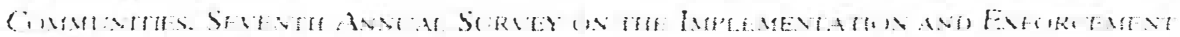
of Coma vir Evirkmandal Law 2005 (Commission Staff Working Paper 1143.

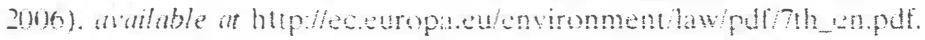

and The Commision does not have any formal competence to ensure compliance with

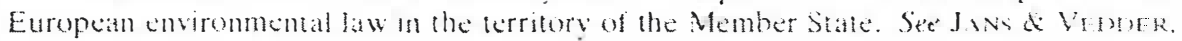
supra norc 2323 at 151

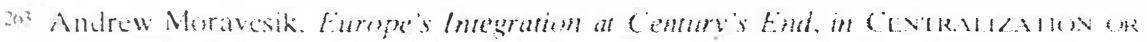

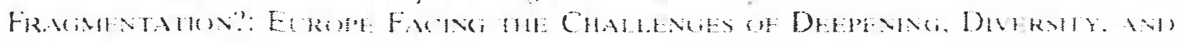

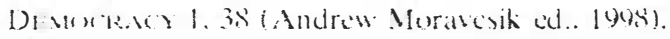


have a relative advantage. Of course, countries such as Spain may themselves have been reluctant to fully implement and enforce the tough and ostensibly uniform European environmental standards. Hence, the enlargement of the EU creates a situation in which the protectionist motive for environmental regulatory centralization is basically absent. If protectionism is indeed an important force behind the movement for real environmental regulatory centralization - for uniform standards that are actually implemented and enforced uniformly across the federation - then we should see relatively little concern with lax environmental standards in the new EU nations.

\section{CONCLUDING REMARKS}

We have attempted to analyze environmental federalism in two seemingly different legal systems, the U.S. on the one hand and the European Union on the other. Such a comparison is. repeating the quote by Krämer in the introduction, "necessarily misleading." "2n+t There are of course large differences between the two systems: indeed, even in the language one notices the dangers of comparison. For example, when an American scholar refers to "national standards," he refers to federal standards as opposed to local or state standards; for a European scholar a "national standard" necessarily refers to a standard set by the national Member State, as opposed to either a local or a European standard.

Despite these institutional differences, we believe that the comparative exercise is informative and illuminating. Although the law and economics literature has recommended that when externalities cross state borders. it becomes especially important to shift powers to a regulatory level which has jurisdiction over a territory large enough to adequately deal with the problem. ${ }^{2 n 5}$ centralized environmental regulation in Europe and in the United States has not really been focused on such inter-jurisdictional pollution problems. From an economic perspective, both U.S. federal and European environmental laws are much more extensive than might be necessary to cure an interstate externality. Hence, as the stylized facts in Section 2 showed. centralization of environmental matters both in

3at Kramer. supra note th at 155 ("The European Union (EC) does not enjoy the presrogatives of a state: it may act only where it has been expressly so authorised by the Treaty. Any comparison with demestic environmental law in the Member States. or with that of the USA is therefore necessarily miskading.").

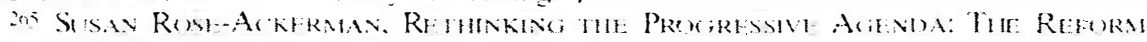

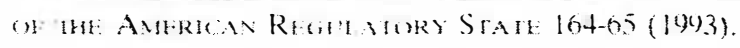


the U.S. and in Europe goes much further than the economic literature has predicted.2xt

As we have seen, in hoth Europe and in the U.S.. the courts have struck down as unconstitutional (or as violating the European Treaty) state (or national Member state) environmental laws that impose too large a burden on interstate trade. Whether these judgments promote efficiency depends very much on the specifie circumstances. On the one hand, the ECJ's Diasseldorp decision may have prevented national authorities from shifting all waste streams to one monopolistic waste treatment facility, therehy preserving and promoting economies of scale and competition. On the other hand, the U.S. Supreme Court 's cases regarding the interstate market in waste have almost surely cut local incentives to reduce and recycle solid waste. While efficiency effects may be unclear, what does seem clear to us is that by promoting the market for transboundary shipment of waste. the Supreme Court and the ECJ have made it more difficult for states (or Member States) to pursue the goal of hecoming self-sufficient in waste production and disposal. Also, the developments of environmental federalism in both Europe and the U.S. share remarkable parallels: Institutional structures in both regions suggest the development of more centralized. detailed. rule-based regulations, which leave little discretion to Member States, combined with a litigious approach to enforecment. It fits into a pattern which is characterized by Kelemen as "regulatory federalism" whereby federal centers use litigation to constrain reluctant (Member) states, ${ }^{207}$

The pro-federalization stance of the U.S. courts creates another adverse consequence: By broadiy implying the pre-emption of state and local environmental laws by federal environmental laws, the U.S. federal courts have created a situation where, when federal regulations are not adequately enforced, there is no longer the possibility of state and local regulators bridging the gap. In the $\mathrm{EU}$, the reverse problem exists: since the EU has no F:PA with enforcement powers, it is dependent upon Member States to implement and enforce European law. Therefore, the danger in Europe is not so much that Europe would pre-empe national law, hut rather that Member States would ffor a variety of reasons) decide not to implement or enfore European law. The fact that European laws" effectiveness depends on enforcement by the Member States is

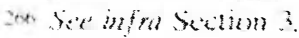

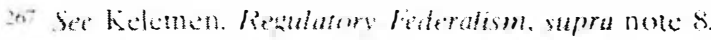


considered by many to be their most significant weakness today. This feature contrasts sharply with the U.S., where the fecleral EPA has direct enforcement power and can (at least in theory) directly control environmental quality in the states if necessary.

Our paper has attempted to use economic analysis of law to provide some explanations for the paradox that, both in the U.S. and in Europe. centralized environmental regulation is concerned primarily with local environmental problems. We have argued, using traditional public choice theory, that the phenomenon can be explained by the relative size of relocation costs. Especially in the U.S. capital, lahor and residency are highly mobile, and there may well be (as the most recent empirical evidence seems to show). a considerable risk of a race to the bottom. which may both explain and justify to some extent centralization in the U.S. The story in Europe appears to be more complicated: cultural, linguistic and (at least in the past) legal and institutional barriers largely prevented inter-jurisdictional mobility of capital, lahor and residency. European industry in Western and Nordic countries like Denmark (and to some extent). Germany, and the Netherlands may have been confronted with a median voter requiring a high level of environmental protection. Where possibilities for capital mobility were traditionally low in Europe, industry did not have the option (as in the U.S.) to move to a jurisdiction where the demand for environmental protection would be lower. Hence, this lower capital mobility also leads to a lower risk of a regulatory race to the bottom in Europe. At the same time, industry in countries with a high demand for environmental protection would lobby to impose tough standards on competitors in other jurisdictions, thus benefiting from their higher levels of environmental regulation by effectively creating barriers to entry.

However, we hypothesize that with the enlargement of the EU in 20()+ and a continuing increase in interjurisdictional mobility of at least capital and labor, the European story may be changing. Facing tough environmental standards in traditional Member States. industry could now benefit from increased inter-jurisdictional mobility for example, by moving to Eastern Europe. Even though Eastern European Member States are formal!y required to comply with the same environmental acquis communatatares. practical enforcement of environmental law may be kess thorough than in the older fifteen EU Member States. If this were the case, one could expect a clecrease of lobbying activities in favor of centralization at the European level - industry would now favor decentrali- 
Zation to take advantage of less stringent environmental standards in the East. Paradoxically. perhaps. EU conlargement may mean that the increasing Europeanization of environmental law is coming to an end. 